\title{
Effect of Anthropogenic Factors on the Ecosystem of the Yenisei River Anabranch within the City of Krasnoyarsk
}

\author{
Elena S. Kravchuk ${ }^{\text {a**, }}$ \\ Olga P. Dubovskaya ${ }^{a, b}$, Svetlana P. Shulepina ${ }^{b}$, \\ Olesya V. Anishchenkoa, Elena A. Ivanova ${ }^{a, b}$, \\ Larisa A. Glushchenkob, Nadezhda N. Sushchik ${ }^{\mathrm{a}, \mathrm{b}}$, \\ Olesia N. Makhutovaa,b, Anzhelika A. Kolmakova ${ }^{a}$, \\ Alexander P. Tolomeev ${ }^{\mathrm{a}, \mathrm{b}}$, Anton V. Drobotov ${ }^{\mathrm{a}}$, \\ Alexander V. Ageev ${ }^{b}$, Inna I. Morozova ${ }^{b}$, \\ Yuliya D. Anishchenko a and Michail I. Gladyshev, \\ "Institute of Biophysics $S B R A S$, \\ FRC "Krasnoyarsk Science Center SB RAS" \\ Krasnoyarsk, Russian Federation \\ ${ }^{b}$ Siberian Federal University \\ Krasnoyarsk, Russian Federation
}

Received 09.10.2020, received in revised form 19.10.2020, accepted 23.10.2020, published online 23.11.2020

\begin{abstract}
In recent decades, freshwater ecosystems have regularly experienced blooms of green algae (green tides), causing environmental and economic damage. Blooms of green alga Spirogyra sp. occur in the 'Abakanskaya' anabranch of the Yenisei River in summer months. The anabranch is influenced by several anthropogenic factors: construction of a dam in the upper reaches; heated water discharge from a thermal power plant; fish farming. The aim of this study was to assess the impact of anthropogenic factors on the ecosystem of the Abakanskaya anabranch and to identify the main factors favoring Spirogyra sp. blooms. Samples were taken in May-September 2018-2019 at four sites: 1 - upstream of the dam (control), 2 - downstream of the dam, 3 - near the point of heated water discharge, 4 - downstream of the fish farm. Physical and chemical parameters, biomass and species composition of phytoplankton, phytoperiphyton, zooplankton, zoobenthos, and higher water plants, gross primary production (GPP), nitrogen content in biomass of periphyton, higher plants, and
\end{abstract}

(C) Siberian Federal University. All rights reserved

This work is licensed under a Creative Commons Attribution-NonCommercial 4.0 International License (CC BY-NC 4.0).

* Corresponding author E-mail address: kravchuk@ibp.krasn.ru

ORCID: 0000-0003-3185-6322 (Kravchuk E.); 0000-0003-3759-0510 (Shulepina S.); 0000-0002-1976-599X (Anishchenko O.); 0000-0002-3220-103X (Ivanova E.); 0000-0001-5623-1121 (Glushchenko L.); 0000-0001-5587-9807 (Sushchik N.); 0000-0002-9387-5054 (Makhutova O.); 0000-0002-9124-4566 (Tolomeev A.); 0000-0003-1717-0092 (Morozova I.); 0000-0002-7438-0347 (Anishchenko Yu.); 0000-0003-2276-3095 (Gladyshev M.) 
zoobenthos were studied. The main factor that caused changes in the community was that there was no water flow in the anabranch because of the low capacity of the dam drainage pipes. While upstream of the dam most ecosystem features were within the limits typical for this part of the Yenisei River, downstream of the dam, the system seemed to change from lotic to lentic: percentage of motile forms of phytoplankton, biomass of zooplankton, percentage of true zooplankton species, taxon number and taxonomic diversity of zooplankton and zoobenthos became higher; phytoperiphyton primary production rose (because of Spirogyra sp. bloom); higher water plants thrived. The other investigated factors, namely, thermal, nutrient, and organic pollution evidently produced combined effect on the ecosystem because of the absence of water flow, and their specific effects were not obvious.

Keywords: Spirogyra sp., harmful algal blooms, metaphyton, dam, flow alteration, thermal pollution, aquaculture, eutrophication.

Acknowlegements. The project «Assessment of the ecological state of the Abakanskaya branch of the Yenisei River in Krasnoyarsk, determination of the premises for its deterioration and development of recommendations for its improvement» was funded by Krasnoyarsk Regional Fund of Science. This research was funded by the State Assignment within the framework of the fundamental research program of the Russian Federation, topic No. 51.1.1; the Government Assignment given by Ministry of Science and Higher Education of Russian Federation to Siberian Federal University in 2020 (Project No. FSRZ-2020-0006, "Biologically active components in ecological, biotechnological, and medical systems").

Citation: Kravchuk E.S., Dubovskaya O.P., Shulepina S.P., Anishchenko O.V., Ivanova E.A., Glushchenko L.A., Sushchik N.N., Makhutova O.N., Kolmakova A.A., Tolomeev A.P., Drobotov A.V., Ageev A.V., Morozova I.I., Anishchenko Yu.D., Gladyshev M.I. Effect of anthropogenic factors on the ecosystem of the Yenisei River anabranch within the city of Krasnoyarsk. J. Sib. Fed. Univ. Biol., 2021, 14(2), 208-237. DOI: 10.17516/1997-1389-0331 


\title{
Влияние антропогенных факторов \\ на экосистему протоки р. Енисей \\ в черте города Красноярска
}

\author{
Е.С. Кравчука, О.П. Дубовская ${ }^{a, ~}{ }^{a}$, С.П. Шулепина ${ }^{\sigma}$, \\ О.В. Анищенко ${ }^{a}$ Е. А. Иванова ${ }^{a}, \sigma$, Л. А. Глущенко ${ }^{\sigma}$, \\ Н.Н. Сущик, ${ }^{a,}$, О.Н. Махутова ${ }^{a, \sigma}$, А. А. Колмакова ${ }^{a}$, \\ А.П. Толомеев ${ }^{\mathrm{a}, \boldsymbol{\sigma}}$, А. В. Дроботов ${ }^{\mathrm{a}}$, А.В. Агеев ${ }^{\tilde{6}}$, \\ И. И. Морозова ${ }^{\sigma}$ Ю. Д. Анищенко ${ }^{a}$ М.И. Гладышев, \\ ${ }^{a}$ Институт биофизики СО РАН \\ ФИЦ «Красноярский научный центр СО РАН» \\ Российская Федерачия, Красноярск \\ ${ }^{6}$ Сибирский федеральный университет \\ Российская Федерачия, Красноярск
}

\begin{abstract}
Аннотация. В последние десятилетия в пресноводных экосистемах часто наблюдается массовый рост зеленых водорослей («зеленые приливы»), вызывающий негативные экологические и экономические последствия. Абаканская протока р. Енисей, в которой в летние месяцы происходит массовое развитие зеленой водоросли Spirogyra sp., подвержена влиянию ряда антропогенных факторов: верховье протоки перекрыто дамбой, в протоку сбрасываются подогретые воды ТЭЦ, работает рыборазводное хозяйство. Целью данной работы было оценить влияние антропогенных факторов на экосистему Абаканской протоки и выявить основные факторы, способствующие массовому росту в ней спирогиры. Пробы отбирали в мае-сентябре 2018-2019 гг. на четырех станциях: 1 - выше дамбы (фон), 2 - ниже по течению от дамбы, 3 - в районе поступления подогретых вод ТЭЦ, 4 - ниже рыбоводных садков. Оценивали физические и химические показатели, биомассу и видовой состав фитопланктона, фитоперифитона, зоопланктона, зообентоса и высших водных растений (ВВР), валовую первичную продукцию (ВПП), содержание азота в биомассе перифитона, ВВР и зообентоса. Показано, что в результате низкой пропускной способности дренажных труб дамбы в протоке отсутствует стоковое течение воды, что является основным фактором, вызывающим перестройку сообщества. Если выше дамбы большинство показателей находилось в пределах, характерных для данного участка p. Енисей, то на нижележащем участке наблюдаются признаки перехода лотической системы в лентическую: возрастает доля подвижных форм фитопланктона, биомасса зоопланктона, доля представителей истинного планктона, число таксонов и таксономическое разнообразие зоопланктона и зообентоса, ВПП фитоперифитона (за счет интенсивного роста Spirogyra sp.), появляются заросли ВВР. Другие исследованные факторы - тепловое, биогенное и органическое загрязнение - в связи с отсутствием стокового течения, очевидно, действовали на экосистему в комплексе, и их специфические эффекты в явном виде не были замечены.
\end{abstract}

Ключевые слова: Spirogyra sp., вредоносное «цветение» водорослей, метафитон, дамба, изменение проточности, тепловое загрязнение, аквакультура, эвтрофирование. 
Благодарности. Проект «Оценка экологического состояния Абаканской протоки реки Енисей в г. Красноярске, определение предпосылок его ухудшения и выработка рекомендаций по его улучшению» проделан при поддержке Красноярского краевого фонда науки. Работа поддержана Государственным заданием в рамках программы фундаментальных исследований РФ, тема № 51.1.1; Государственным заданием Министерства науки и высшего образования Российской Федерации Сибирскому федеральному университету на 2020 год (проект № FSRZ-2020-0006, тема проекта «Биологически активные вещества в экологических, биотехнологических и медицинских системах»).

Цитирование: Кравчук, Е.С. Влияние антропогенных факторов на экосистему протоки р. Енисей в черте города Красноярска / Е. С. Кравчук, О.П. Дубовская, С.П. Шулепина, О. В. Анищенко, Е. А. Иванова, Л. А. Глущенко, Н.Н. Сущик, О.Н. Махутова, А. А. Колмакова, А. П. Толомеев, А. В. Дроботов, А. В. Агеев, И. И. Морозова, Ю. Д. Анищенко, М. И. Гладышев // Журн. Сиб. федер. ун-та. Биология, 2021. 14(2). С. 208-237. DOI: 10.17516/1997-1389-0331

\section{Введение}

Деятельность человека с каждым годом оказывает все большее влияние на пресноводные экосистемы (Søndergaard, Jeppesen, 2007). Изменение среды под воздействием антропогенных факторов неизбежно приводит к изменению структурных и функциональных показателей сообщества организмов, населяющих водный объект (Bunn, Arthington, 2002). Перестройка водорослевого сообщества зачастую сопровождается снижением видового разнообразия и массовым развитием отдельных видов («цветение» воды цианопрокариотами, «зеленые приливы» нитчатых водорослей), что, в свою очередь, может вызывать ухудшение качества воды, гипоксию, заболачивание и ряд других проблем (Gladyshev, Gubelit, 2019; Burford et al., 2020).

Влияние различных антропогенных факторов (в частности, зарегулирования стока, сброса загрязненных и подогретых вод, аквакультуры) на речные экосистемы интенсивно изучается на протяжении десятилетий (Bunn, Arthington, 2002; Podemski, Blanchfield, 2006; Zargar, Ghosh, 2006; Ruiz-Zarzuela et al., 2009; Poff, Zimmerman, 2010; Czerniawski et al., 2013; Mavraganis et al., 2017; Ruzickova et al., 2017; Wang et al., 2018; Nashaat et al., 2019). Однако в подавляющем большинстве случаев исследо- ватели рассматривают изменения, вызываемые одним определенным типом воздействия на одну (реже несколько) группу организмов. Работ, в которых оценивалось бы одновременное воздействие нескольких факторов на все звенья экосистемы, нами при анализе рецензируемых научных источников не найдено. С одной стороны, это, вероятно, связано со сложностью интерпретации комплексного влияния на экосистему. С другой стороны, исследуемые источники антропогенного воздействия должны быть расположены в достаточной близости друг от друга, иначе будет сложно отделить их влияние от изменений в сообществе, вызванных пространственной разобщенностью. Поэтому все еще достаточно сложно оценить результаты совместного влияния разных антропогенных факторов на экосистему водотока.

В черте г. Красноярска расположена Абаканская протока р. Енисей, которая является одним из любимых мест отдыха горожан. Однако в последние годы в Абаканской протоке в летние месяцы происходит интенсивный рост зеленой водоросли Spirogyra sp., значительная масса которой скапливается и разлагается на поверхности воды, что приводит к потере Абаканской протокой рекреационных свойств. Протока подвержена интенсивному антропо- 


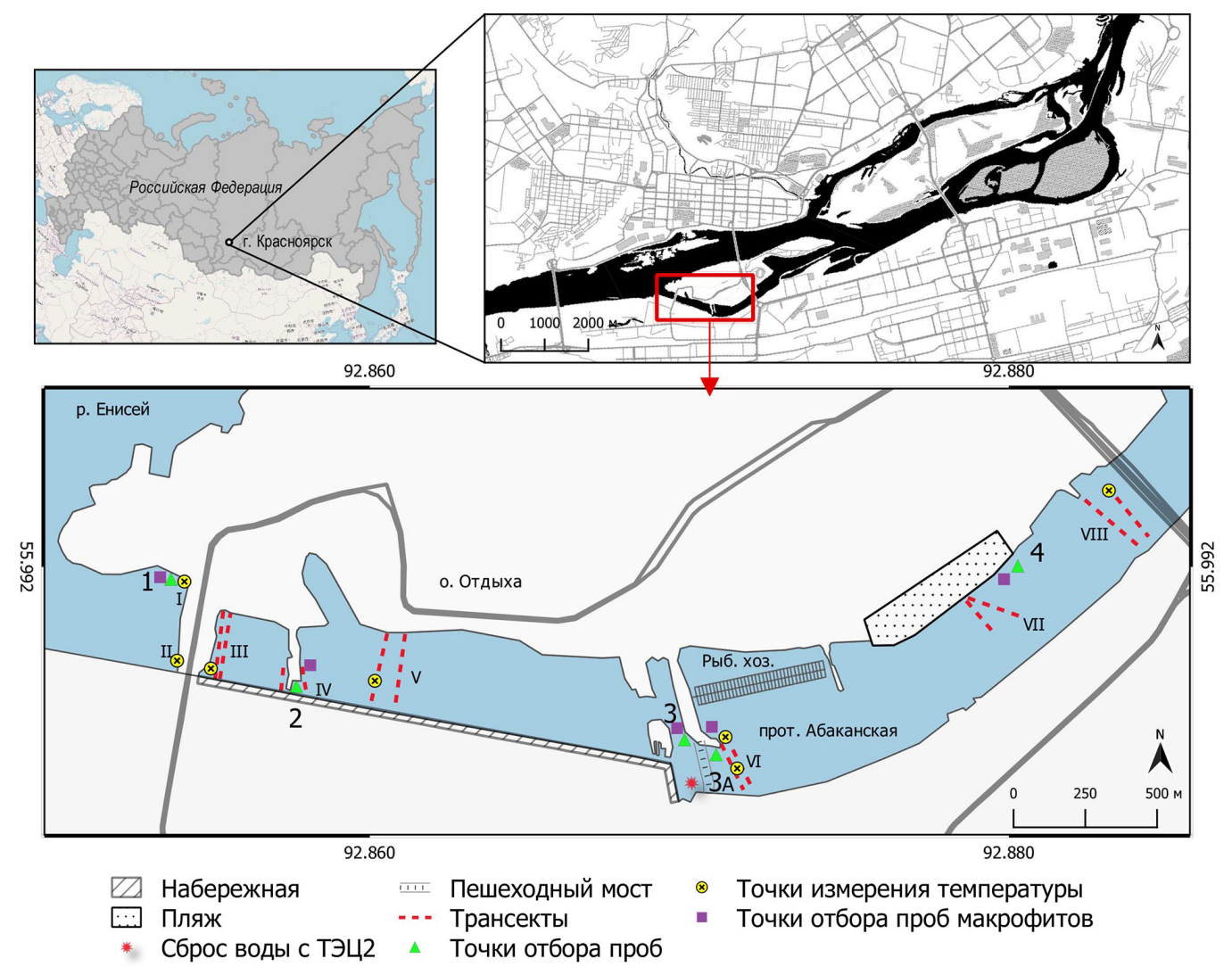

Рис. 1. Карта-схема Абаканской протоки р. Енисей

Fig. 1. Diagrammatic map of the 'Abakanskaya' anabranch of the Yenisei River

генному прессу: верховье протоки перекрыто дамбой, в протоку сбрасываются подогретые воды ТЭЦ, работает рыборазводное хозяйство; это позволяет использовать ее как модельный объект для исследования одновременного воздействия ряда антропогенных факторов. Целью данной работы было оценить влияние антропогенных факторов на экосистему Абаканской протоки р. Енисей и попытаться выявить основные факторы, способствующие массовому развитию в ней Spirogyra sp.

\section{Район и методы исследования}

Абаканская протока р. Енисей (5559' с.ш., 9251' в.д.) расположена в центре г. Красноярска между островом Отдыха и правым берегом (рис. 1). В верхней части русло прото- ки перекрывает дамба, по которой проходит автомобильная дорога. Возле правого берега через дамбу проложены две трубы, обеспечивающие частичный пропуск воды между верхней и основной частями протоки. Ниже по течению в нескольких местах находятся искусственные насыпи, представляющие собой защитный слой проходящих по дну протоки дюкеров. Возле одной из таких насыпей организовано рыборазводное хозяйство и установлены садковые линии для выращивания и выдерживания рыбы. В центральной части Абаканской протоки у правого берега через рассеивающий выпуск осуществляется сброс теплой технологической воды ТЭЦ 2. Кроме того, в нескольких местах в протоку поступают городские ливневые стоки. 
Дно протоки сложено каменисто-галечными грунтами. Из-за сброса глубинных вод Красноярского водохранилища, расположенного в 35 км выше по течению, протока подвержена периодическим колебаниям уровня. Летом прибрежная зона интенсивно используется населением в рекреационных целях на острове Отдыха расположен городской пляж, лодочный причал, прогулочные дорожки, а вдоль правого берега проходит городская набережная.

Работы проводили в 2018 и 2019 гг. В 2018 г. пробы отбирали на четырех станциях левого берега, различающихся по уровню антропогенной нагрузки (рис. 1): станция 1 находилась в 50 м выше дамбы на условно фоновом участке протоки; станция 2 - 200 м ниже по течению от дамбы и отражала изменения, происходящие в экосистеме при зарегулировании стока; станция 3 - в районе поступления подогретых вод ТЭЦ; станция 4 - 500 м ниже рыбоводных садков и возле городского пляжа. Пробы на каждой станции отбирали 31 мая, 28 июня, 23 июля и 27 августа. В 2019 г. пробы были взяты на тех же станциях 28 мая, 27 июня, 23 июля, 7 и 27 августа и 11 сентября. Дополнительно 7 и 27 августа и 11 сентября 2019 г. пробы отбирали на станции 3а (рис. 1).

Пробы отбирали возле берега на глубине 0,5-0,7 м. Воду для оценки видового состава и количественных показателей фитопланктона, определения содержания хлорофилла «а», гидрофизических и гидрохимических анализов зачерпывали пластиковым ведром. Температуру воды измеряли электронным термометром Long-Stem Thermometer, F/C, 8 (ColeParmer, США), содержание растворенного кислорода - кислородомером НI 9142 (Hanna Instruments, США), pH - с помощью лабораторного рН-метра PB-11 (Sartorius, Германия).

Для определения видового состава, численности и биомассы фитопланктона про- бы воды объемом 400 мл фильтровали через мембранные фильтры ОС-2 (Владипор, Россия; диаметр пор 0,45 мкм). Для отбора проб фитоперифитона на дно помещали стальную рамку 10x10 см, из которой изымали гальку. Обрастания снимали с субстрата с помощью щетки и помещали в банку с небольшим количеством речной воды. Пробы фитопланктона и перифитона консервировали фиксатором на основе раствора Люголя в модификации Г.В. Кузьмина. Определение видового состава и численности водорослей проводили в камере Фукса-Розенталя объемом 3,2 мкл. Размеры клеток определяли с помощью окуляр-микрометра. Биомассу рассчитывали по объему клеток, приравнивая удельную массу к единице (Руководство по гидробиологическому мониторингу..., 1992).

На каждой станции проводили измерения интенсивности фотосинтетически активной радиации (ФАР) с помощью наземного поверхностного сенсора LI-190 SA и регистрирующего устройства LI-COR 1400 (LI-COR Ltd., CШA), а также измерения подводной освещенности погружными сенсорами LI-193SA и LI-192SA (LI-COR Ltd., США) (Tolomeev et al., 2014) у поверхности, на глубинах $0,4-0,5$ м и $0,75-1$ м, в зависимости от максимальной глубины. Эвфотическая зона на участках наблюдений достигала дна.

Валовая первичная продукция (ВПП) фитопланктона и перифитона была рассчитана на основе содержания хлорофилла «а» и потенциальной фотосинтетической активности микроводорослей и цианобактерий. Для определения содержания хлорофилла «а» пробы речной воды (в среднем 500 мл) и суспензии фитоперифитона (100 мл), полученной разведением исходных проб в $4-60$ раз, фильтровали через мембранные фильтры с размером пор 0,45 мкм (Владипор, Россия), с подложкой из суспензии $\mathrm{MgCO}_{3}$. Экстракцию 
хлорофилла проводили в 90\%-ном этаноле с предварительным кипячением в течение 10 мин. После остывания пробы держали при $4{ }^{\circ} \mathrm{C}$ в течение 14 ч, затем температуру доводили до комнатной, центрифугировали и определяли оптическую плотность супернатанта с помощью спектрофотометра SmartSpec Plus (BioRad, CША) с поправкой на феофетин, до и после подкисления $3 \mathrm{M} \mathrm{HCl}$ (3 мкл раствора соляной кислоты на 3 мл экстракта), по формуле, представленной в работе (Nusch, 1980).

Для определения потенциальной фотосинтетической активности фитопланктона и фитоперифитона (относительной вариабельной флуоресценции) была измерена флуоресценция ( $\lambda=685$ нм) проб до и после добавления ингибитора электрон-транспортной цепи фотосинтеза - симазина (2-хлор-4,6-бис (этиламино)-с-триазин) с помощью индукционного флуориметра ФЛ-304 (Сибирский федеральный университет, Красноярск, Россия) (Анищенко, 2008) непосредственно после доставки проб в лабораторию.

Для каждого горизонта была вычислена ВПП фитопланктона $\left(\mathrm{r}_{2} /\left(\mathrm{M}^{3} \cdot \mathrm{u}\right)\right)$, согласно (Gaevsky et al., 2000):

$$
\text { ВПП=6,227 } \cdot 10^{-3} \cdot \text { Хл } a \cdot \Delta \text { Фл/Фл }{ }_{\mathrm{M}} \cdot \sqrt{I}_{z},
$$

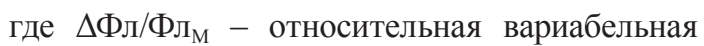
флуоресценция (отн. ед.); Хл а - концентрация хлорофилла «а» планктона (мг/M³) в пробе, принятая для столба воды; $\mathrm{I}_{\mathrm{z}}$ - среднечасовая интенсивность ФАР (Вт/м²) на данном горизонте.

Относительная вариабельная флуоресценция рассчитывалась по формуле

$$
\Delta \text { лл/ФЛ }
$$

где Фл $_{0}$ - флуоресценция хлорофилла без добавления ингибитора; Фл ная флуоресценция в присутствии 10 мкМ

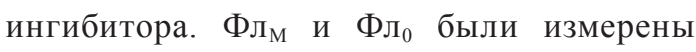
при возбуждении широкой областью (400620 нм).

Для расчета средних часовых величин приходящей на поверхность ФАР (Is) данные по суммарной суточной солнечной радиации (МДж/(м².сут)), полученные с помощью алгоритма, представленного на сайте (https:// power.larc.nasa.gov/data-access-viewer), были пересчитаны с учетом длины светового дня (http://dateandtime.info/ru/citysunrisesunset), переведены в Вт/м² (переводной коэффициент Дж в Вт - 1/3600), умножены на принятый для умеренных широт коэффициент 0,46 для перевода в ФАР. Коэффициент ослабления освещенности водной толщи $\mathrm{K}_{0}$ оценивали по измерениям подводной ФАР сферическим датчиком освещенности LI-193SA по общепринятой формуле (Kirk, 2010). Измерения, проведенные на воздухе наземным сенсором LI-190 SA и в верхнем слое воды плоским датчиком LI-192SA, позволили оценить входящую в воду ФАР, и для каждой станции в даты отбора проб был введен определенный коэффициент ослабления света при переходе из воздушной в водную среду $(Q)$. Все подводные измерения были нормированы по показаниям наземного сенсора LI-190 SA. Таким образом, расчет ФАР (Iz, ВТ/M²) на горизонтах водной толщи проводили по формуле

$$
\mathrm{Iz}=Q \cdot I_{s} \cdot e^{-K_{0} z}
$$

где z - глубина горизонта (м); $K_{0}^{z}$ - коэффициент ослабления света на глубине $z$.

Данные о ВПП на изученных горизонтах интегрировали по глубине для оценки продукции под $\mathrm{M}^{2}$ и затем, для определения суточной величины ВПП $\left(г \mathrm{O}_{2} /\left(\mathrm{M}^{2} \cdot\right.\right.$ сут) $)$, умножали на длину светового дня.

ВПП перифитона $\left(г \mathrm{O}_{2} /\left(\mathrm{M}^{2} \cdot \mathrm{\varphi}\right)\right.$ и $\mathrm{\Gamma O}_{2} /$ $\left(\mathrm{M}^{2} \cdot\right.$ сут)) оценивали по формуле (1), данные по 
концентрации хлорофилла «а» пересчитывали на м² поверхности дна.

Сбор высших водных растений проводили возле берега методом укосов фитомассы с учетных площадок с помощью рамки размером 30 х 30 см в 2-6 повторностях (Катанская, 1981). В районе станции 3 пробы отбирали с обеих сторон насыпи (рис. 1), полученные данные усредняли. 25 июля 2019 г. пробы были отобраны с лодки в районе тех же станций, но в центральной части протоки. Укосы разбирали по видам растений. Растения промывали проточной водой и высушивали в сушильном шкафу при $105{ }^{\circ} \mathrm{C}$ до постоянного вeca.

Пробы воды для гидрохимических анализов фильтровали через планктонный газ с размером ячеи 130 мкм. Содержание биогенных элементов определяли по общепринятым методикам: аммонийный азот - по методу Несслера с использованием светофильтра 440 нм (ГОСТ 33045-2014); нитритный азот - колориметрическим методом с использованием реакции с сульфаниламидом и а-нафтиламином (реактив Грисса) (ГОСТ 33045-2014); нитратный азот переводили в нитритный редукцией на кадмиевой колонке (РД 52.24.380 - 2017). Содержание общего и минерального фосфора анализировали фотометрическим методом согласно (РД 52.24.387 - 2006), (РД 52.24.382 - 2006). Содержание общего азота в пробах фитоперифитона, зообентоса и макрофитов определяли на элементном анализаторе Flash 2000 NC Soil Analyzer (Thermo Fisher Scientific, Германия) (Gladyshev et al., 2007).

Зоопланктон отбирали фильтрованием 70-200 л воды через сеть Апштейна (размер ячеи 82 мкм). Воду зачерпывали пластиковым ведром объемом 10 л. Пробы фиксировали 4\%-ным формалином. Камеральную обработку проб проводили методом Утер- меля под инвертированным микроскопом Leica DM IL LED (Leica Microsystems GmbH, Германия). Массу организмов находили по линейным размерам с помощью уравнений связи длины и массы тела (Руководство по гидробиологическому мониторингу..., 1992; Алимов и др., 2013). При разделении видов по приуроченности к местообитанию (планктонный, бентосный, фитофильный) руководствовались сведениями из определителей и из статьи (Walseng et al., 2006).

Пробы зообентоса отбирали в двукратной повторности из металлической рамки 40x40 см с помощью гидробиологического скребка с размером ячеи 224 мкм. Затем в лаборатории беспозвоночных выбирали из пробы пинцетами и фиксировали в 80\%-ном этаноле. Биомассу рассчитывали по фиксированным в спирте животным, взвешивание проводили на торсионных весах (тип WT) с дискретностью определения массы до 1 мг (Руководство по гидробиологическому мониторингу..., 1992).

Видовое разнообразие сообществ фитопланктона, фитоперифитона, зоопланктона и зообентоса оценивали с помощью индекса Шеннона (Schultz et al., 2013). Видовой состав сообществ на разных станциях сравнивали с помощью индекса Соренсена, который рассчитывали по формуле $\mathrm{Ks}=2 \cdot \mathrm{c} /(\mathrm{a}+\mathrm{b})$, где с - число общих видов для двух станций; $\mathrm{a}$ - число видов на первой станции; b - число видов на второй станции (Методика..., 1975). Качество воды определяли по индексу сапробности (методом Пантле и Букка) в модификации Сладечека (Макрушин, 1974). Индивидуальные индексы сапробности взяты из литературных источников, для водорослей из (Водоросли, 1989; Баринова и др., 2000), для зоопланктона и зообентоса - из (Унифицированные методы, 1977; Sladecek, 1973; Wegl, 1983). По величинам индекса сапроб- 
ности устанавливали класс качества воды согласно (РД 52.24.309-2011).

Натурные измерения гидрологических параметров были выполнены на двух стационарных станциях (I, II, рис. 1) и шести трансектах (III - VIII, рис. 1) в период 25.07.2019 - 01.08.2019. Первые два участка были расположены на расстоянии 300 м от входа в Абаканскую протоку с внешней стороны дорожной дамбы (рис. 1). Сразу за дамбой выделен участок III и за ним на расстоянии 150 м короткий участок IV, заполняющий пространство между правым берегом и косой, вдающейся вглубь протоки со стороны острова Отдыха. За косой на расстоянии 300 м следовал участок $\mathrm{V}$, отражающий значительную часть протоки до второй островной косы, которая оканчивалась понтонным пешеходным мостом. Трансекта участка VI проходила параллельно понтонному мосту от края косы к правому берегу (рис. 1). Трансекта участка VII располагалась напротив городского пляжа, приблизительно в центре между второй островной косой и Коммунальным мостом. И, наконец, трансекта участка VIII проходила вдоль Коммунального моста.

Скорости течений (восточная и северная компоненты) и профили дна были измерены c помощью ADCP профайлера (614.4 кГц) WorkHorse Sentinel 600 (RDI Equipment, США). Измерение осуществляли с поверхности воды. Устройство располагалось на буксируемом плоту в вертикальном положении. Трансдьюсеры были погружены в воду на 18 см. Промер трансект осуществляли путем буксировки ADCP профайлера моторной лодкой со скоростью 0,5 м/с. Начало и конец измерений трансект соответствовали границам береговой линии за исключением участка VII. В этом месте правая сторона протоки имела высокую плотность зарослей макрофитов, что не позволяло осуществить изме- рения выбранным способом. Каждая трансекта промерялась два раза. Конфигурация устройства для измерений скоростей течений по трансектам задавалась следующими параметрами: 1st Bin =0,31 м, Bin $\operatorname{Size}=0,20$ м, Pings/Ens = 10. Период измерений на стационарных станциях составлял не менее 10 мин, параметры конфигурации были выставлены следующие: 1 st Bin =0,34 м, Bin Size =0,10 м, Pings/Ens = 15. Измерения профилей температуры и электропроводности проводили с помощью зонда CastAway-CTD (YSI, CША) со встроенным GPS-приемником точечно на исследуемых станциях и трансектах (рис. 1). Полученные скорости течений были обработаны и проанализированы с использованием программного обеспечения WinADCP (v1.14, Teledyne RD Instruments) и R-package «oce» (Kelley, 2018). Постобработка данных заключалась в проверке надежности полученных значений скоростей и расчета потоков воды $\left(\mathrm{M}^{3} /\left(\mathrm{M}^{2} \cdot \mathrm{c}\right)\right)$ через трансекты в прямом и обратном направлении относительно основного течения р. Енисей. Значения скоростей, имеющих низкую степень надежности (correlation magnitude < 64), были исключены из расчетов согласно техническим рекомендациям по работе с RDA-инструментами, например (Alberty et al., 2017). Ошибки измерения обычно связаны с такими неблагоприятными факторами, как интерференция сигнала на мелководных участках, неравномерность буксировки профайлера, рассеивание сигнала макрофитами, мальками рыб и т.д.

Достоверность различий средних оценивали с помощью анализа ANOVA, с последующей процедурой post hoc на основе критерия Тьюки, а также с помощью критерия Стьюдента и критерия Краскела-Уоллиса. Нормальность распределения проверяли по критерию Колмогорова-Смирнова. 


\section{Результаты}

Гидрофизические параметры

Наибольшие глубины (до 2,7 м в среднем по трансекте, максимальная глубина 4,6 м у правого берега на трансекте V) характерны для реки и верхней части протоки, в то время как в районе пляжа (транссекты VII - VIII) средняя глубина снижается до 1 м (табл. 1). Измеренные средние по трансекте скорости течений в толще воды (независимо от направлений) находились в диапазоне $360-550$ мм/с и не имели достоверных отличий между трансектами. Величины потоков воды через трансекты варьировали в диапазоне $0,1-0,8 \mathrm{~m}^{3} /\left(\mathrm{M}^{2} \cdot \mathrm{c}\right)$, достоверных отличий между ними также не было (табл. 1).

Точечные измерения температуры воды на станциях отбора проб показали, что температура в реке (ст. 1) и ниже дамбы (ст. 2) была в среднем достоверно меньше на $6-9^{\circ} \mathrm{C}$, чем на участке сброса подогретых вод ТЭЦ (ст. 3) и в нижней части протоки (ст. 4) (рис. 2). При измерении зондом вертикального распределения температуры воды обнаружено, что на глубоководном участке ниже дамбы (трансекта V) наблюдалась температурная стратификация, разница температур поверхностного и придонного слоев воды составляла $7,6{ }^{\circ} \mathrm{C}$ (табл. 1).

Минерализация воды (по удельной электропроводности, УЭП) на второй и четвертой станциях в протоке в среднем была достоверно выше по post hoc критерию Тьюки, чем в реке (рис. 3, табл. 1). Максимальные значения УЭП отмечали на глубоководном участке протоки ниже дамбы (ст. 2, трансекты III - V) (рис. 3, табл. 1).

\section{Гидрохимические параметры}

Концентрация растворенного кислорода в нижней части протоки, в точке ниже рыбного хозяйства (ст. 4), была в среднем выше на 1 - 2 мг/л, чем в реке (ст. 1) и в верхней части протоки (ст. 2 - 3), однако достоверными оказались только различия между ст. 2 и 4 (рис. 2). Среднее значение $\mathrm{pH}$ на ст. 4 также было достоверно выше, чем на остальных станциях (рис. 2). Среднее значение концентрации аммонийного азота $\mathrm{NH}_{4}-\mathrm{N}$ на участке сброса подогретых вод ТЭЦ (ст. 3) превышало таковые на остальных станциях, однако эти различия оказались статистически недостоверными (рис. 2). Средние концентрации нитритного азота $\mathrm{NO}_{2}-\mathrm{N}$ в реке (ст. 1) и ниже дамбы (ст. 2) практически не отличались, но имели тенденцию к увеличению на ст. 3 , а на ст. 4 становились достоверно выше, чем на ст. 1 и 2 (рис. 2). Средние значения концентраций нитратного азота $\mathrm{NO}_{3}-\mathrm{N}$ и минерального фосфора $\mathrm{PO}_{4}-\mathrm{P}$ достоверно не различались между всеми станциями (рис. 2). Средние значения концентраций общего фосфора имели тенденцию увеличения в нижней части протоки: концентрации этого элемента на ст. 4 были достоверно выше, чем на ст. 2 (рис. 2).

\section{Фитопланктон}

Общая биомасса фитопланктона (без учета нитей Spirogyra) на всех станциях была низкой и значительно варьировала (рис. 4), распределение отличалось от нормального по критерию Колмогорова-Смирнова, и различия средних значений оказались недостоверными по критерию Краскела-Уоллиса. Доминирующее положение на всем обследованном участке протоки занимали в основном бентосные и планкто-бентосные виды диатомовых и зеленых водорослей и цианопрокариот (рис. 4, табл. 2). Однако на всех станциях ниже дамбы существенный вклад в биомассу также вносили истинно-планктонные виды золотистых, динофитовых и криптофитовых водорослей (на рис. 4 показаны как группа «прочие»), некоторые представители которых 

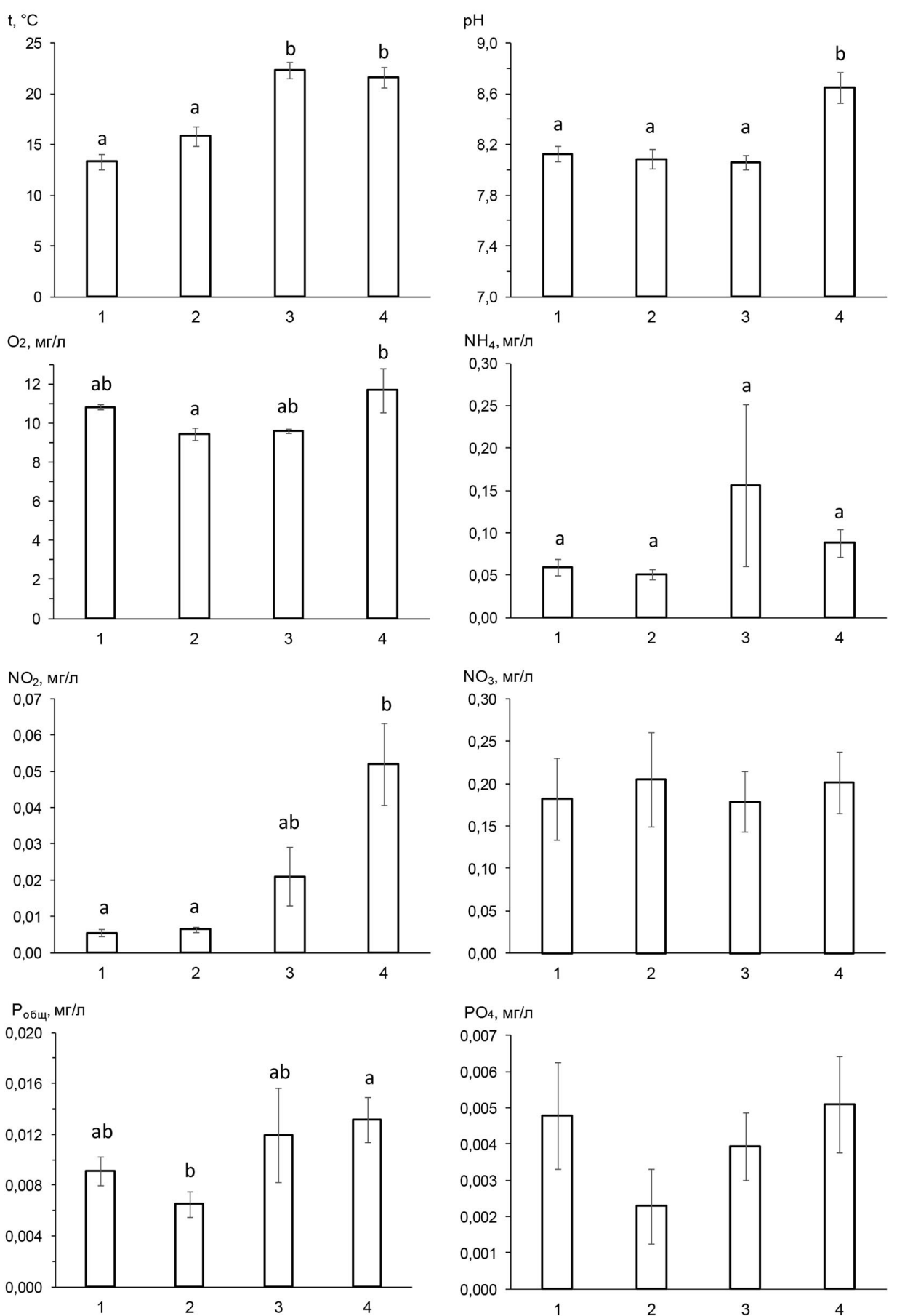

Рис. 2. Средние значения гидрохимических показателей и их стандартные ошибки (SE) в Абаканской протоке р. Енисей, 2018-2019 гг. Средние, отмеченные одинаковыми буквами, достоверно не отличаются по posthoc критерию Тьюки в дисперсионном анализе (ANOVA) в случае нормального распределения по критерию Колмогорова-Смирнова или по критерию Краскела-Уоллиса (ненормальное распределение). При недостоверном ANOVA буквенные обозначения отсутствуют

Fig. 2. Mean values of hydrochemical characteristics ( \pm standard error) in the 'Abakanskaya' anabranch of the Yenisei River, 2018-2019. The same letters denote means that are not significantly different based on Tukey's posthoc test (ANOVA) in case of normal distribution (Kolmogorov-Smirnov test) or based on Kruskal-Wallis test in case of non-normal distribution. No letters indicates that ANOVA is not significant 
Таблица 1. Гидрофизические характеристики Абаканской протоки р. Енисей, измеренные в период 25 июля - 1 августа 2019 г. Достоверность различий в скоростях течений оценена с помощью дисперсионного анализа и критерия Стьюдента. Различия в показателях электропроводности оценены с помощью дисперсионного анализа и процедуры post hoc с использованием критерия Тьюки. Одинаковыми буквами отмечены средние, между которыми отличия статистически не достоверны

Table 1. Hydrophysical characteristics of the Abakanskaya anabranch of the Yenisei River measured 25 July 1 August 2019. The significance of differences between flow rates was determined by ANOVA or Student's t-test. The significance of differences between electroconductivity values were estimated by ANOVA coupled with Tukey's posthoc test. The same letters denote means that are not significantly different

\begin{tabular}{|c|c|c|c|c|c|c|}
\hline \multirow[t]{2}{*}{$\begin{array}{c}\text { Тран- } \\
\text { секты/ } \\
\text { участки }\end{array}$} & \multirow[t]{2}{*}{$\begin{array}{c}\text { Средняя } \\
\text { глубина } \\
\text { (м) }\end{array}$} & \multirow[t]{2}{*}{$\begin{array}{c}\text { Диапазон } \\
\text { температур, } \\
{ }^{\circ} \mathrm{C}\end{array}$} & \multirow[t]{2}{*}{$\begin{array}{c}\text { Удельная } \\
\text { электро- } \\
\text { проводность } \\
\text { (мкСм/см) }\end{array}$} & \multirow{2}{*}{$\begin{array}{c}\text { Средние скорости течений } \\
\text { в толще воды независимо } \\
\text { от направления (мм/c), } \\
\text { ANOVA, F = } 1,844, \\
\mathrm{p}<0,075 \\
\mathrm{M} \pm \mathrm{SE}\end{array}$} & \multicolumn{2}{|c|}{$\begin{array}{c}\text { Поток воды через } \\
\text { трансекты } \\
\left(\mathrm{M}^{3} /\left(\mathrm{M}^{2} \cdot \mathrm{c}\right)\right), \text { для всех } \\
\text { значений различия не } \\
\text { достоверны, } \\
\text { t-test }<1,42, \mathrm{p}<0,16\end{array}$} \\
\hline & & & & & $\begin{array}{c}\text { вниз, } \\
\mathrm{M} \pm \mathrm{SE}\end{array}$ & $\begin{array}{l}\text { вверх, } \\
M \pm S E\end{array}$ \\
\hline I & 1,9 & $15,0-15,3$ & $161,8 \pm 0,1^{\mathrm{a}}$ & $483,9 \pm 20,8$ & - & - \\
\hline II & 1,4 & $15,2-16,5$ & $163,4 \pm 0,5^{\mathrm{a}}$ & $463,3 \pm 20,9$ & - & - \\
\hline III & 2,3 & $10,9-13,2$ & $234,1 \pm 8,6^{b}$ & $551,4 \pm 27,6$ & $0,41 \pm 0,03$ & $0,50 \pm 0,05$ \\
\hline IV & 1,8 & $13,4-14,3$ & $213,5 \pm 10,7^{b c}$ & $356,9 \pm 51,1$ & $0,22 \pm 0,09$ & $0,10 \pm 0,08$ \\
\hline $\mathrm{V}$ & 2,7 & $8,1-15,7$ & $280,1 \pm 16,7^{\mathrm{d}}$ & $457,1 \pm 21,1$ & $0,56 \pm 0,06$ & $0,50 \pm 0,05$ \\
\hline VI & 2,1 & $20,4-21,7$ & $178,8 \pm 1,2^{\mathrm{ac}}$ & $416,4 \pm 21,7$ & $0,48 \pm 0,06$ & $0,47 \pm 0,05$ \\
\hline VII & 1,0 & - & - & $536,8 \pm 45,7$ & $0,78 \pm 0,11$ & $0,74 \pm 0,13$ \\
\hline VIII & 1,3 & $22,0-22,2$ & $193,6 \pm 1,0^{\mathrm{abc}}$ & $480,0 \pm 32,2$ & $0,48 \pm 0,06$ & $0,55 \pm 0,08$ \\
\hline
\end{tabular}

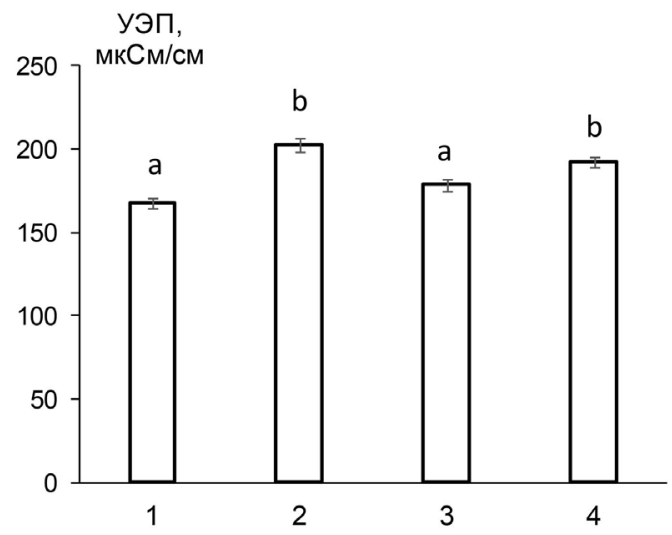

Рис. 3. Средние значения удельной электропроводности (мкСм/см) и их стандартные ошибки (SE) в Абаканской протоке р. Енисей, 2018-2019 гг. Средние, отмеченные одинаковыми буквами, достоверно не отличаются по posthoc критерию Тьюки в дисперсионном анализе (ANOVA)

Fig. 3. Mean values of specific conductivity $(\mu \mathrm{S} / \mathrm{cm}, \pm$ standard error) in the 'Abakanskaya' anabranch of the Yenisei River, 2018-2019. The same letters denote means that are not significantly different based on Tukey's posthoc test (ANOVA) 

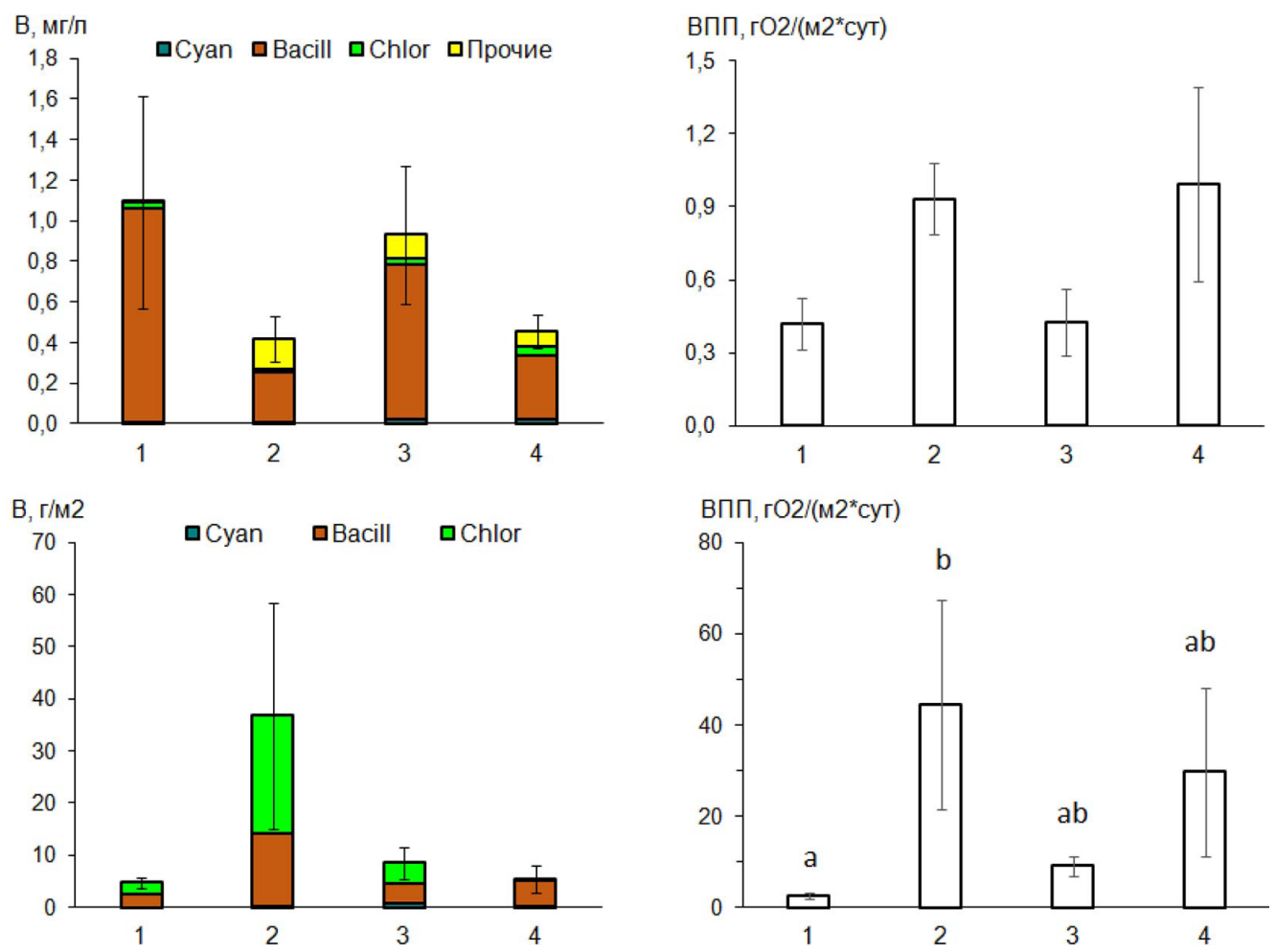

Рис. 4. Средние значения биомассы (В) и валовой первичной продукции (ВПП) фитопланктона (вверху) и фитоперифитона (внизу) и их стандартные ошибки (SE) в Абаканской протоке р. Енисей, 2018-2019 гг. В группу «Прочие» входят Chrysophyceae, Dinophyceae, Cryptophyta, Euglenophyceae, Xanthophyceae. Средние, отмеченные одинаковыми буквами, достоверно не отличаются по критерию Краскела-Уоллиса. При недостоверном критерии буквенные обозначения отсутствуют

Fig. 4. Mean values of biomass (B) and gross primary production (GPP) of phytoplankton (top) and phytoperiphyton (bottom) ( \pm standard error) in the 'Abakanskaya' anabranch of the Yenisei River, 2018-2019. "Others" includes Chrysophyceae, Dinophyceae, Cryptophyta, Euglenophyceae, Xanthophyceae. The same letters denote means that are not significantly different based on Kruskal-Wallis test. No letters means that test is not significant

(Dinobryon sociale var. stipitatum, Cryptomonas erosa) на ст. 2 занимали доминирующее положение (табл. 2). Значительных различий по общему числу видов между станциями не было. Усредненный за все время наблюдения коэффициент Соренсена между всеми станциями варьировал от 0,31 до 0,44 (табл. 2), демонстрируя низкую степень сходства видового состава.

\section{Фитоперифитон}

Общая биомасса фитоперифитона (без учета Spirogyra sp.) в реке (ст. 1) и в нижней части протоки (ст. 3 и 4) была невысокой (рис. 4), средние значения между станциями достоверно не различались. Биомасса перифитона на участке ниже плотины (ст. 2) была в среднем выше, чем на остальных станциях, однако это отличие оказалось статистически недостоверным по критерию Краскела-Уоллиса. Как в реке (ст. 1), так и в верхней части протоки (ст. 2 и 3) доминировали диатомовые и нитчатые зеленые водоросли (рис. 4, табл. 3), тогда как в нижней части протоки (ст. 4) перифитон был в основном представлен диатомовыми водорослями. На ст. 3 заметный вклад (около 10 \%) также вносили цианопрокариоты (рис. 4), среди которых 
Таблица 2. Доминирующие по биомассе таксоны фитопланктона, их приуроченность к местообитанию (Р - планктонный, В - бентосный, Р-В - планкто-бентосный), общее число таксонов и средние значения коэффициентов сходства Соренсена ( \pm стандартная ошибка) в Абаканской протоке р. Енисей в 20182019 гг.

Table 2. Dominant biomass taxa of phytoplankton, their habitat ( $\mathrm{P}$ - planktonic, $\mathrm{B}$ - benthic, $\mathrm{P}-\mathrm{B}$ - planktonicbenthic), total taxon number and mean values of Sorensen Index of Similarity ( \pm standard error) in the 'Abakanskaya' anabranch of the Yenisei River in 2018-2019

\begin{tabular}{|c|c|c|c|c|c|}
\hline Доминант & $\begin{array}{c}\text { Место- } \\
\text { обитание }\end{array}$ & Ст. 1 & Ст. 2 & Ст. 3 и $3 \mathrm{a}$ & Ст. 4 \\
\hline \multicolumn{6}{|l|}{ Cyanoprokaryota } \\
\hline Oscillatoria limosa Ag. & $\mathrm{B}$ & & & & + \\
\hline \multicolumn{6}{|l|}{ Bacillariophyta } \\
\hline Achnanthes minutissima Kutz & $\mathrm{B}$ & & & & + \\
\hline Amphora ovalis (Kutz.) Kutz. & $\mathrm{B}$ & & + & & \\
\hline Cocconeis pediculus Ehr. & B & & & & + \\
\hline Cymatopleura solea (Bréb.) W.Sm. & $\mathrm{B}$ & + & & + & \\
\hline Cymbella cymbiformis Ag. & $\mathrm{B}$ & & + & & \\
\hline Cymbella ventricosa Kutz. & $\mathrm{B}$ & & & + & + \\
\hline Didymosphenia geminata (Lyngb.) M.Schm. & $\mathrm{B}$ & + & & & \\
\hline Fragilaria capucina Desm. & $P$ & + & & & \\
\hline Melosira islandica O. Müll. & $\mathrm{P}$ & & & + & + \\
\hline Melosira varians Ag. & P-B & + & & + & \\
\hline Stephanodiscaceae & & + & + & + & + \\
\hline Synedra acus Kutz. & $\mathrm{P}$ & + & + & + & \\
\hline Synedra ulna (Nitzsch) Ehr. & B & + & & & \\
\hline \multicolumn{6}{|l|}{ Chlorophyta } \\
\hline Ulotrix zonata Kutz. & $\mathrm{B}$ & & & + & \\
\hline \multicolumn{6}{|l|}{ Charophyta } \\
\hline Closterium acerosum Ehr. ex Ralfs & $\mathrm{B}$ & + & & & \\
\hline \multicolumn{6}{|l|}{ Chrysophyceae } \\
\hline Dinobryon sociale var. stipitatum (Stein) Lemm. & $\mathrm{P}$ & & + & & \\
\hline \multicolumn{6}{|l|}{ Cryptophyta } \\
\hline Cryptomonas erosa Ehr. & $\mathrm{P}$ & & + & & \\
\hline \multirow[t]{2}{*}{ Общее число таксонов } & & 51 & 54 & 57 & 58 \\
\hline & \multicolumn{5}{|c|}{ Коэффициент сходства Соренсена } \\
\hline Ст. 2 & & $0,37 \pm 0,04$ & & & \\
\hline Ст. 3 и $3 \mathrm{a}$ & & $0,41 \pm 0,04$ & $0,39 \pm 0,04$ & & \\
\hline СТ. 4 & & $0,34 \pm 0,04$ & $0,31 \pm 0,03$ & $0,38 \pm 0,02$ & \\
\hline
\end{tabular}

преобладала Oscillatoria limosa (табл. 3). Общее число таксонов на всех станциях было близким. Значения коэффициента Соренсена
(0,37 - 0,49) свидетельствуют о средней степени сходства видового состава между станциями (табл. 3). 
Таблица 3. Доминирующие по биомассе таксоны фитоперифитона, общее число таксонов и средние значения коэффициентов сходства Соренсена ( \pm стандартная ошибка) в Абаканской протоке р. Енисей в 2018-2019 гг.

Table 3. Dominant biomass taxa of phytoperiphyton, total taxon number and mean values of Sorensen Index of Similarity ( \pm standard error) in the 'Abakanskaya' anabranch of the Yenisei River in 2018-2019

\begin{tabular}{|c|c|c|c|c|}
\hline Доминант & Ст. 1 & Ст. 2 & Ст. 3 и $3 \mathrm{a}$ & Ст. 4 \\
\hline \multicolumn{5}{|l|}{ Cyanoprokaryota } \\
\hline Oscillatoria limosa Ag. & & & + & \\
\hline \multicolumn{5}{|l|}{ Bacillariophyta } \\
\hline Achnanthes lanceolata (Breb.) Grun. & + & + & & + \\
\hline Aulacoseira granulata (Ehr.) Sim. & & & + & \\
\hline Cocconeis pediculus Ehr. & & & + & + \\
\hline Cymatopleura elliptica (Breb.) W.Sm. & & & & + \\
\hline Cymbella cistula (Hemp.) Grun. & & & & + \\
\hline Cymbella stuxbergii $\mathrm{Cl}$. & & & + & \\
\hline Cymbella ventricosa Kutz. & & + & + & \\
\hline Fragilaria sp. & & + & & \\
\hline Gomphonema olivaceum (Lyngb.) Kutz. & + & & & \\
\hline Gomphonema ventricosum Greg. & + & & & \\
\hline Melosira varians Ag. & & & + & + \\
\hline Navicula radiosa Kutz. & & + & & \\
\hline Pinnularia sp. & & + & & \\
\hline Synedra ulna (Nitzsch) Ehr. & + & & + & + \\
\hline \multicolumn{5}{|l|}{ Chlorophyta } \\
\hline Stigeoclonium tenue Kutz. & & & & + \\
\hline Ulothrix zonata Kutz. & + & + & + & \\
\hline \multicolumn{5}{|l|}{ Charophyta } \\
\hline Mougeotia sp. & + & & + & \\
\hline Общее число таксонов & 42 & 42 & 47 & 44 \\
\hline \multicolumn{5}{|l|}{ Коэффициент сходства Соренсена } \\
\hline Ст. 2 & $0,44 \pm 0,03$ & & & \\
\hline Ст. 3 и $3 \mathrm{a}$ & $0,40 \pm 0,04$ & $0,38 \pm 0,04$ & & \\
\hline Ст. 4 & $0,37 \pm 0,03$ & $0,41 \pm 0,02$ & $0,46 \pm 0,04$ & \\
\hline
\end{tabular}

Валовая первичная продукичия

Валовая первичная продукция (ВПП) фитопланктона и перифитона в реке (ст. 1) была относительно низкой (рис. 4). Средние значения ВПП фитопланктона на всех четыpeх станциях достоверно не отличались по критерию Краскела-Уоллиса. ВПП перифитона на ст. 2 была достоверно выше, чем на ст. 1, тогда как между другими станциями не было достоверных различий (рис. 4). В целом на всех станциях ВПП фитоперифитона на порядок превышала ВПП фитопланктона. 

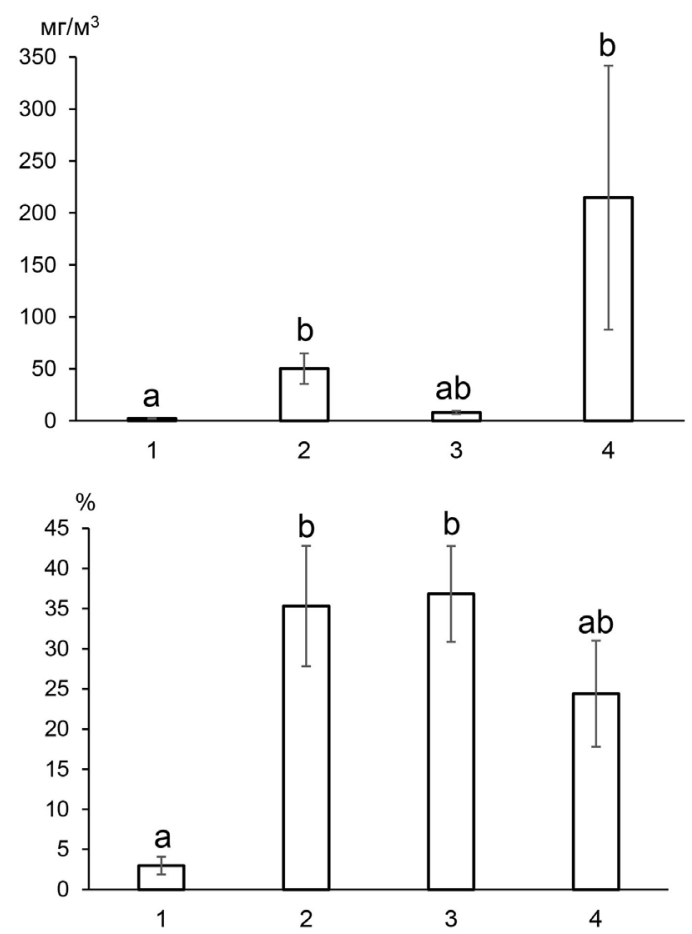

Рис. 5. Средние значения биомассы зоопланктона и доли (\%) истинного (пелагического) зоопланктона в общей биомассе, включая планктобентос и фитофильный зоопланктон, и их стандартные ошибки (SE) в Абаканской протоке р. Енисей, 2018-2019 гг. Средние, отмеченные одинаковыми буквами, достоверно не отличаются по критерию Краскела-Уоллиса (общая биомасса) и posthoc критерию Тьюки в дисперсионном анализе (ANOVA, доля истинного зоопланктона, нормальность распределения подтверждена по критерию Колмогорова-Смирнова)

Fig. 5. Mean values of zooplankton biomass and percentage ( $\%$ ) of the true (pelagic) zooplankton in total biomass, including planktobenthos and phytophylic zooplankton, ( \pm standard error) in the 'Abakanskaya' anabranch of the Yenisei River, 2018-2019. The same letters denote means that are not significantly different based on Kruskal-Wallis test (total biomass) and Tukey's posthoc test (ANOVA, percentage of the true zooplankton, normality of distribution is supported by Kolmogorov-Smirnov test)

\section{Зоопланктон}

Биомасса зоопланктона в реке (ст. 1) была достоверно ниже, чем на ст. 2 и 4 в протоке (рис. 5). Доля истинного (пелагического лимнического) зоопланктона в общей биомассе зоопланктона была достоверно выше в верх-

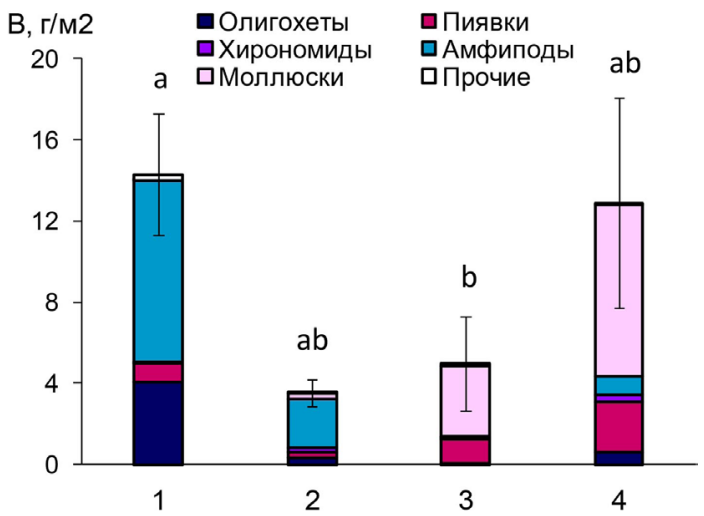

Рис. 6. Средние значения биомассы зообентоса и их стандартные ошибки (SE) в Абаканской протоке p. Енисей, 2018-2019 гг. (в группу «Прочие» входят ручейники, двукрылые, веснянки, поденки, стрекозы и жуки). Средние, отмеченные одинаковыми буквами, достоверно не отличаются по критерию Краскела - Уоллиса

Fig. 6. Mean values of zoobenthos biomass ( \pm standard error) in the 'Abakanskaya' anabranch of the Yenisei River, 2018-2019 ("others" includes Trichoptera, Diptera, Plecoptera, Ephemeroptera, Odonata, and Coleoptera). The same letters denote means that are not significantly different based on Kruskal-Wallis test

ней части протоки (ст. 2 - 3), чем в реке (ст. 1) (рис. 5). В нижней части протоки на ст. 4 доля истинного зоопланктона имела тенденцию к снижению по сравнению со станциями 2 и 3 и достоверно не отличалась от речной ст. 1 (рис. 5). Однако на ст. 1 зоопланктон был представлен в основном речными бентическими видами (например, Harpacticella inopinata), тогда как на ст. 4 - фитофильными (зарослевыми) и планктонными видами (табл. 4). На ст. 2 в составе доминантов преобладали планктонные и планкто-бентосные виды, а на ст. 3 бентосные (табл. 4). Общее число видов 30опланктона на второй и третьей станциях было в полтора раза выше, а на четвертой - в два раза выше, чем на первой станции. При сравнении верхней и нижележащих станций индекс Соренсена варьировал от 0,30 до 0,36; видовой состав станций 2-4 был более сходным - индекс Соренсена составил 0,43 - 0,47 (табл. 4). 
Таблица 4. Доминирующие по биомассе таксоны зоопланктона, их приуроченность к местообитанию ( $\mathrm{P}$ - планктонный, В - бентосный, Р-B - планкто-бентосный, $\mathrm{Ph}$ - фитофильный), общее число таксонов и средние значения коэффициентов сходства Соренсена ( \pm стандартная ошибка) в Абаканской протоке р. Енисей в 2018-2019 гг.

Table 4. Dominant biomass taxa of zooplankton, their habitat ( $\mathrm{P}$ - planktonic, $\mathrm{B}$ - benthic, $\mathrm{P}-\mathrm{B}$ - planktonicbenthic, $\mathrm{Ph}$ - phytophylic), total taxon number and mean values of Sorensen Index of Similarity ( \pm standard error) in the 'Abakanskaya' anabranch of the Yenisei River in 2018-2019

\begin{tabular}{|c|c|c|c|c|c|}
\hline Доминант и субдоминант & $\begin{array}{c}\text { Место- } \\
\text { обитание }\end{array}$ & Ст. 1 & Ст. 2 & Ст. 3 и $3 \mathrm{a}$ & Ст. 4 \\
\hline \multicolumn{6}{|l|}{ Rotifera } \\
\hline Asplanchna priodonta Gosse & $\mathrm{P}$ & & + & + & + \\
\hline Asplanchnopus multiceps (Schrank) & $\mathrm{P}$ & & & & + \\
\hline Bdelloida & $\mathrm{B}, \mathrm{Ph}$ & + & & + & + \\
\hline Euchlanis dilatata Ehrenberg & $\mathrm{Ph}$ & + & & & \\
\hline Trichocerca longiseta (Schrank) & $\mathrm{Ph}$ & & + & & \\
\hline \multicolumn{6}{|l|}{ Copepoda } \\
\hline nauplii Copepoda & P-B & + & + & + & + \\
\hline copepodits Cyclopoida & P-B & + & + & + & + \\
\hline Cyclops sp. & $\mathrm{P}$ & & & + & \\
\hline Eucyclops serrulatus (Fischer) & $\mathrm{B}$ & + & + & & \\
\hline Harpacticella inopinata G.O. Sars & $\mathrm{B}$ & + & & & \\
\hline Harpacticoida & $\mathrm{B}$ & + & & & \\
\hline \multicolumn{6}{|l|}{ Cladocera } \\
\hline Acroperus harpae (Baird) & $\mathrm{B}$ & & + & & \\
\hline Alona affinis (Leydig) & $\mathrm{B}$ & & & & + \\
\hline Alonella nana (Baird) & B & & + & + & \\
\hline Bosmina longirostris (O.F. Müller) & $\mathrm{P}$ & & + & & + \\
\hline Ceriodaphnia pulchella Sars & P-B & & + & + & \\
\hline Chydorus cf. sphaericus (O.F. Müller) & $\mathrm{P}-\mathrm{B}, \mathrm{Ph}$ & + & & & + \\
\hline Daphnia (Daphnia) galeata Sars & $\mathrm{P}$ & & & & + \\
\hline Eurycercus lamellatus (O.F. Müller) & B & & & & + \\
\hline Ilyocryptus agilis Kurz & $\mathrm{B}$ & & & + & \\
\hline Macrothrix laticornis (Jurine) & B & & & + & \\
\hline Polyphemus pediculus (Linnaeus) & P-B & & + & & \\
\hline Simocephalus vetulus (O.F. Müller) & $\mathrm{Ph}$ & & & & + \\
\hline \multirow[t]{2}{*}{ Общее число таксонов } & & 39 & 62 & 57 & 81 \\
\hline & \multicolumn{4}{|c|}{ Коэффициент сходства Соренсена } & \\
\hline Ст. 2 & & $0,36 \pm 0,03$ & & & \\
\hline Ст. 3 и $3 \mathrm{a}$ & & $0,35 \pm 0,02$ & $0,47 \pm 0,03$ & & \\
\hline Ст. 4 & & $0,30 \pm 0,02$ & $0,47 \pm 0,03$ & $0,42 \pm 0,03$ & \\
\hline
\end{tabular}


Таблица 5. Доминирующие по биомассе таксоны зообентоса, общее число таксонов и средние значения коэффициентов сходства Соренсена ( \pm стандартная ошибка) в Абаканской протоке р. Енисей в 20182019 гг.

Table 5. Dominant biomass taxa of zoobenthos, total taxon number and mean values of Sorensen Index of Similarity ( \pm standard error) in the 'Abakanskaya' anabranch of the Yenisei River in 2018-2019

\begin{tabular}{|c|c|c|c|c|}
\hline Доминант & Ст. 1 & Ст. 2 & Ст. 3 и $3 \mathrm{a}$ & Ст. 4 \\
\hline \multicolumn{5}{|l|}{ Амфиподы } \\
\hline Eulimnogammarus viridis Dub. & + & & & \\
\hline Gmelinoides fasciatus Stebbing & + & + & + & + \\
\hline \multicolumn{5}{|l|}{ Олигохеты } \\
\hline Eiseniella tetraedra Savigny & + & & & \\
\hline Limnodrilus hoffmeisteri Claparede & & & + & \\
\hline \multicolumn{5}{|l|}{ Пиявки } \\
\hline Herpobdella octoculata Linne & + & & + & + \\
\hline \multicolumn{5}{|l|}{ Хирономиды } \\
\hline Cricotopus gr. silvestris & & & + & \\
\hline Polypedilum nubeculosum Meigen & & & + & \\
\hline Potthastia gaedii Meigen & & & + & \\
\hline \multicolumn{5}{|l|}{ Моллюски } \\
\hline Anadonta sp. & & & + & \\
\hline Lymnaea ovata Draparnaud & & & + & + \\
\hline Общее число таксонов & 27 & 50 & 45 & 47 \\
\hline \multicolumn{5}{|l|}{ Коэффициент сходства Соренсена } \\
\hline Ст. 2 & $0,29 \pm 0,04$ & & & \\
\hline Ст. 3 и $3 \mathrm{a}$ & $0,12 \pm 0,04$ & $0,28 \pm 0,04$ & & \\
\hline Ст. 4 & $0,18 \pm 0,04$ & $0,29 \pm 0,04$ & $0,33 \pm 0,06$ & \\
\hline
\end{tabular}

\section{Зообентос}

Среднее значение биомассы зообентоса в реке было достоверно выше по критерию Краскела-Уоллиса, чем на ст. 3 в протоке, тогда как между остальными станциями достоверных различий не было (рис. 6). В реке (ст. 1) и ниже плотины (ст. 2) в биомассе зообентоса преобладали амфиподы и олигохеты (рис. 6, табл. 5), однако в реке среди амфипод доминировал крупный рачок Eulimnogammarus viridis, а в протоке - более мелкий Gmelinoides fasciatus (табл. 5). На ст. 3 и 4 видовой состав зообентоса существенно изменялся - на доминирующее положение выходили пиявки, моллюски, а на ст. 3 в отдельные даты также хирономиды (рис. 6, табл. 5). Общее число таксонов зообентоса, обнаруженных в реке на ст. 1, было ниже, чем в протоке на ст. 2 - 4 (табл. 5). Существенные различия видового состава зообентоса в реке и на двух нижних станциях протоки (3 и 4) подтверждаются низкой величиной индекса Соренсена $(0,12$ и $0,18)$, тогда как для остальных пар станций он варьирует в пределах 0,28-0,33 (табл. 5). 

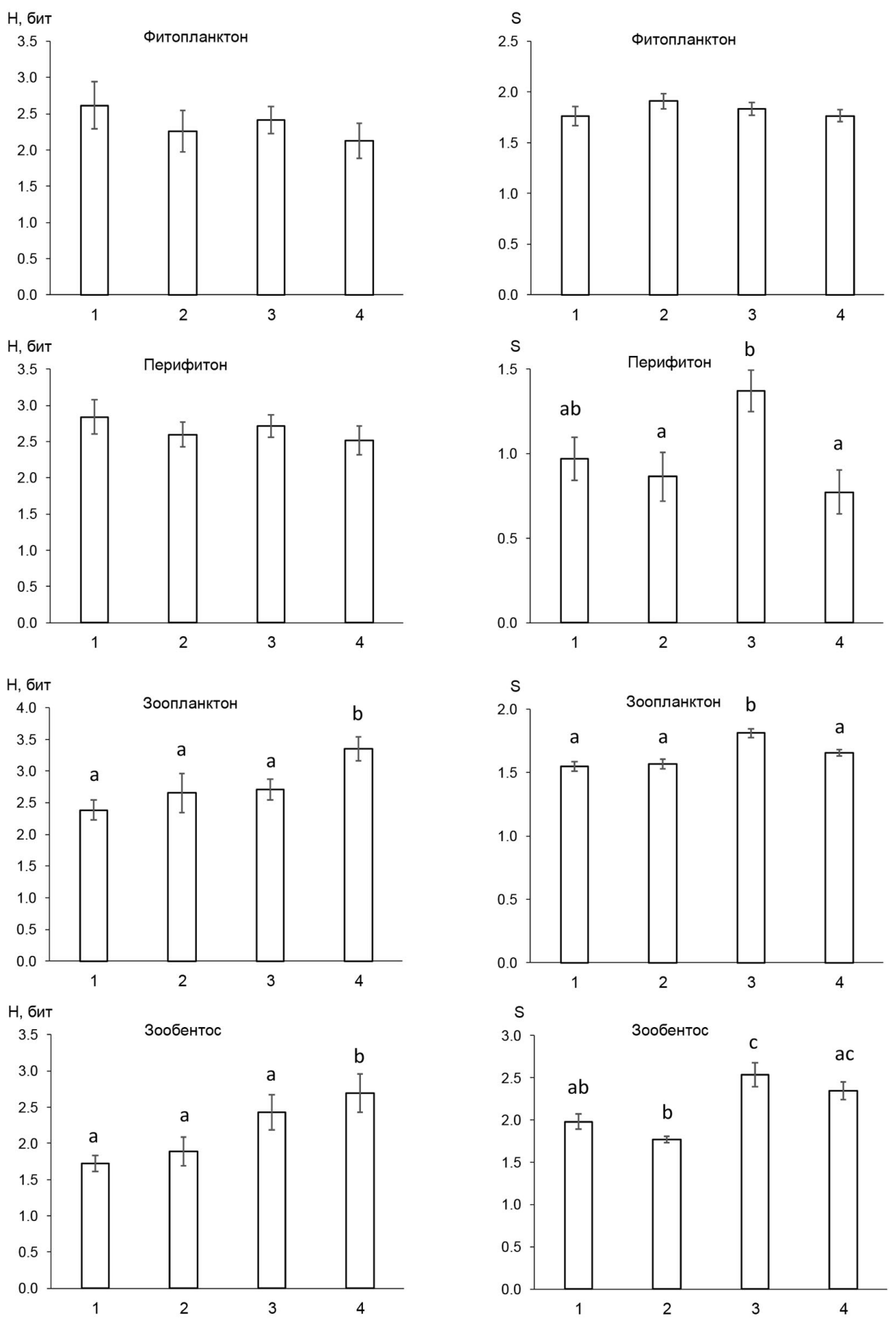

Рис. 7. Средние значения индекса Шеннона (слева), индекса сапробности (справа) и их стандартные ошибки (SE), рассчитанные по численности видов фитопланктона, перифитона, зоопланктона и зообентоса в Абаканской протоке р. Енисей, 2018-2019 гг. Средние, отмеченные одинаковыми буквами, достоверно не отличаются по posthoc критерию Тьюки в дисперсионном анализе. При недостоверном ANOVA буквенные обозначения отсутствуют

Fig. 7. Mean values of Shannon index (left) and saprobity index (right) ( \pm standard error) based on abundance of phytoplankton, periphyton, zooplankton, and zooplankton species in the 'Abakanskaya' anabranch of the Yenisei River, 2018-2019. The same letters denote means that are not significantly different based on Tukey's posthoc test (ANOVA). No letters indicates that ANOVA is not significant 

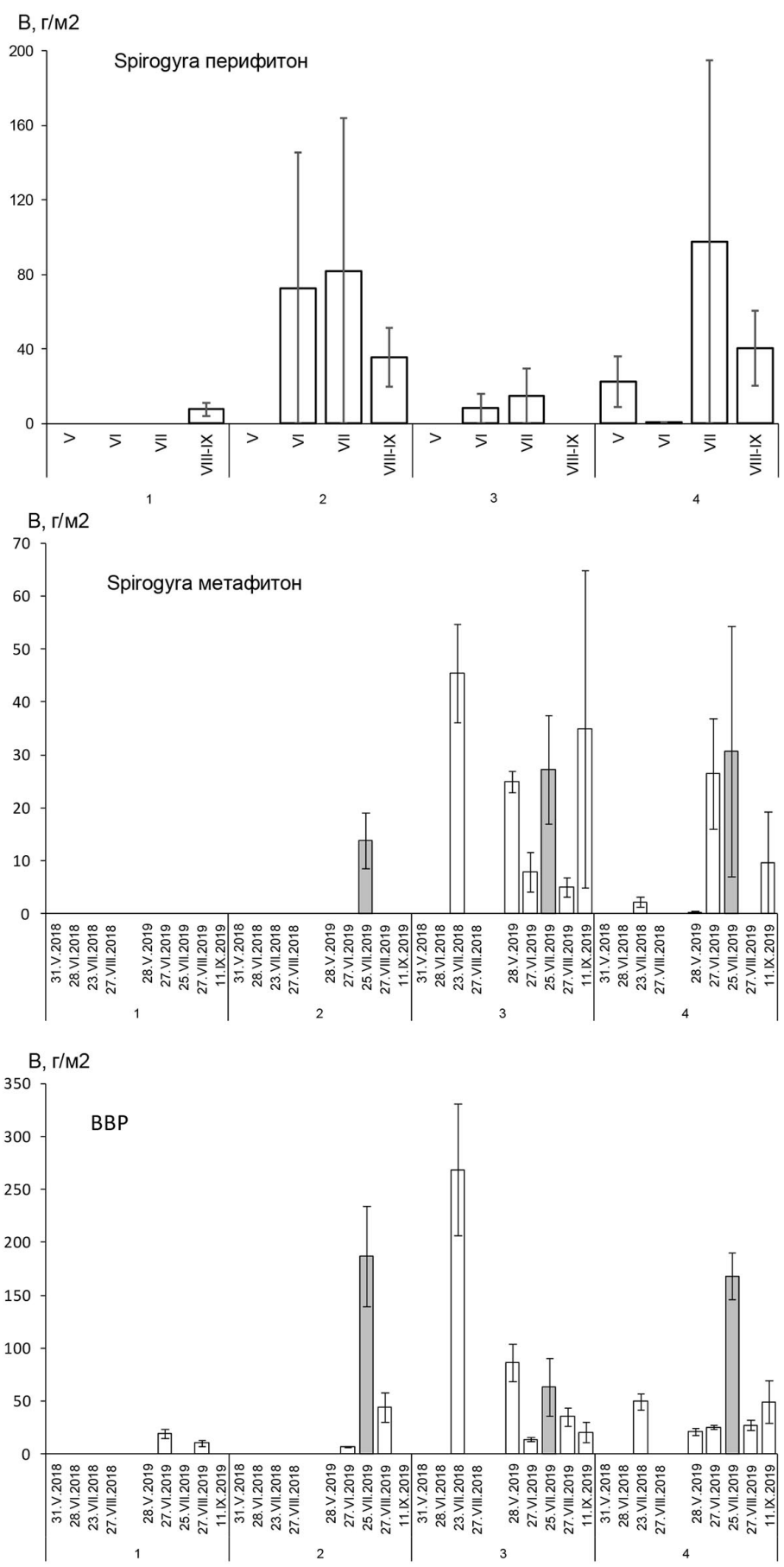

Рис. 8. Средние по месяцам значения биомассы Spirogyra sp. в перифитоне, средние значения сухой биомассы скоплений Spirogyra sp. (метафитон) и высших водных растений (BВР) и их стандартные ошибки (SE) в Абаканской протоке р. Енисей, 2018-2019 гг. Белые столбики - пробы, отобранные возле берега, серые столбики - на глубине в центральной части протоки

Fig. 8. Mean monthly values of Spirogyra sp. biomass in periphyton, mean values of dry biomass of Spirogyra sp. (metaphyton) and higher water plants ( \pm standard error) accumulated in water in the 'Abakanskaya' anabranch of the Yenisei River, 2018-2019. White columns indicate samples taken near the bank; gray columns indicate samples taken in the deep central part of the anabranch 
Индекс Шеннона и качество воды

Видовое разнообразие фитопланктона и фитоперифитона, оцененное с помощью индекса Шеннона (Н), варьировало незначительно, достоверных различий между средними значениями индекса на разных станциях не обнаружено за исключением достоверных различий величин Н зоопланктона и зообентоса на ст. 1 и 4 по post hoc критерию Тьюки (рис. 7).

Среднее значение индекса сапробности $\mathrm{S}$ колебалось от 0,77 до 2,54 балла (рис. 7), что соответствовало 2-му классу качества воды, степени загрязненности «Слабо загрязненная» (РД 52.24.309-2011). Рассчитанные по перифитону значения $\mathrm{S}$ на ст. 3 были достоверно выше по post hoc критерию Тьюки, чем таковые на ст. 2 и 4 (рис. 7). Значения $\mathrm{S}$ для зоопланктона на ст. 3 были достоверно выше, чем на всех остальных станциях (рис. 7). Значения $\mathrm{S}$ для зообентоса на ст. 3 были достоверно выше, чем таковые на ст. 1 и 2 (рис. 7).

Spirogyra sp. и выстая

водная растительность

Spirogyra sp. была встречена в прибрежном перифитоне речной ст. 1 только в августе - сентябре, тогда как в протоке она появлялась существенно раньше - на станциях 2 и 3 в июне - июле, а на станции 4 уже в мае (рис. 8). Наблюдается тенденция к увеличению биомассы Spirogyra sp. на ст. 2 и 4 по сравнению со ст. 1 и 3. В планктоне Spirogyra sp. была обнаружена в оба года исследований только в августе на ст. 4, ее биомасса составляла 0,5-2,9 мг/л (на рис. 8 не показана).

В реке на ст. 1 за все время наблюдений возле берега не было встречено плавающих в толще воды нитей Spirogyra sp. Ниже дамбы (ст. 2) в прибрежье маты Spirogyra sp. также не встречалась, однако при отборе проб в центре протоки биомасса метафитонной стадии Spirogyra sp. оказалась сравнительно высо- кой (рис. 8). На нижележащих станциях 3 и 4 Spirogyra sp. встречалась в толще воды в течение всего вегетационного сезона с мая по сентябрь (рис. 8).

Среди высшей водной растительности Абаканской протоки наиболее распространены следующие виды: элодея канадская (Elodea canadensis Michx.), уруть (предположительно уруть сибирская - Myriophyllum sibiricum Kom.), рдест стеблеобъемлющий (Potamogeton perfoliatus L.), рдест гребенчатый (Potamogeton pectinatus L. syn. Stuckenia pectinata (L.) Börner), роголистник погруженный (Ceratophyllum demersum L.) и шелковник (Batrachium).

В районе ст. 1 высшая растительность развита слабо и в основном представлена видом элодея канадская, заросли которого эпизодически появляются в толще воды возле дамбы. Сложно сказать, растет ли элодея непосредственно в этом районе или же периодически приносится течением из основного русла реки. На всем исследованном участке протоки ниже дамбы высшая растительность хорошо развита и биомасса макрофитов в отдельные даты значительно превышает значения, отмеченные в реке (рис. 8). На ст. 2 в составе макрофитов преобладают представители родов уруть и шелковник. Эти растения характеризуются развитой корневой системой и достаточно прочно прикреплены ко дну, поэтому, несмотря на достаточно высокую биомассу макрофитов, поверхность воды на данном участке остается свободной. На нижележащем участке (ст. 3 и 4) на доминирующее положение выходят виды роголистник погруженный и элодея канадская, а на ст. 4 также представители рода рдест. Поскольку корневая система у роголистника и элодеи слабая, состоит в основном из придаточных корней, они легко отрываются от дна и всплывают в толщу воды. Поэтому поверхность воды ниж- 

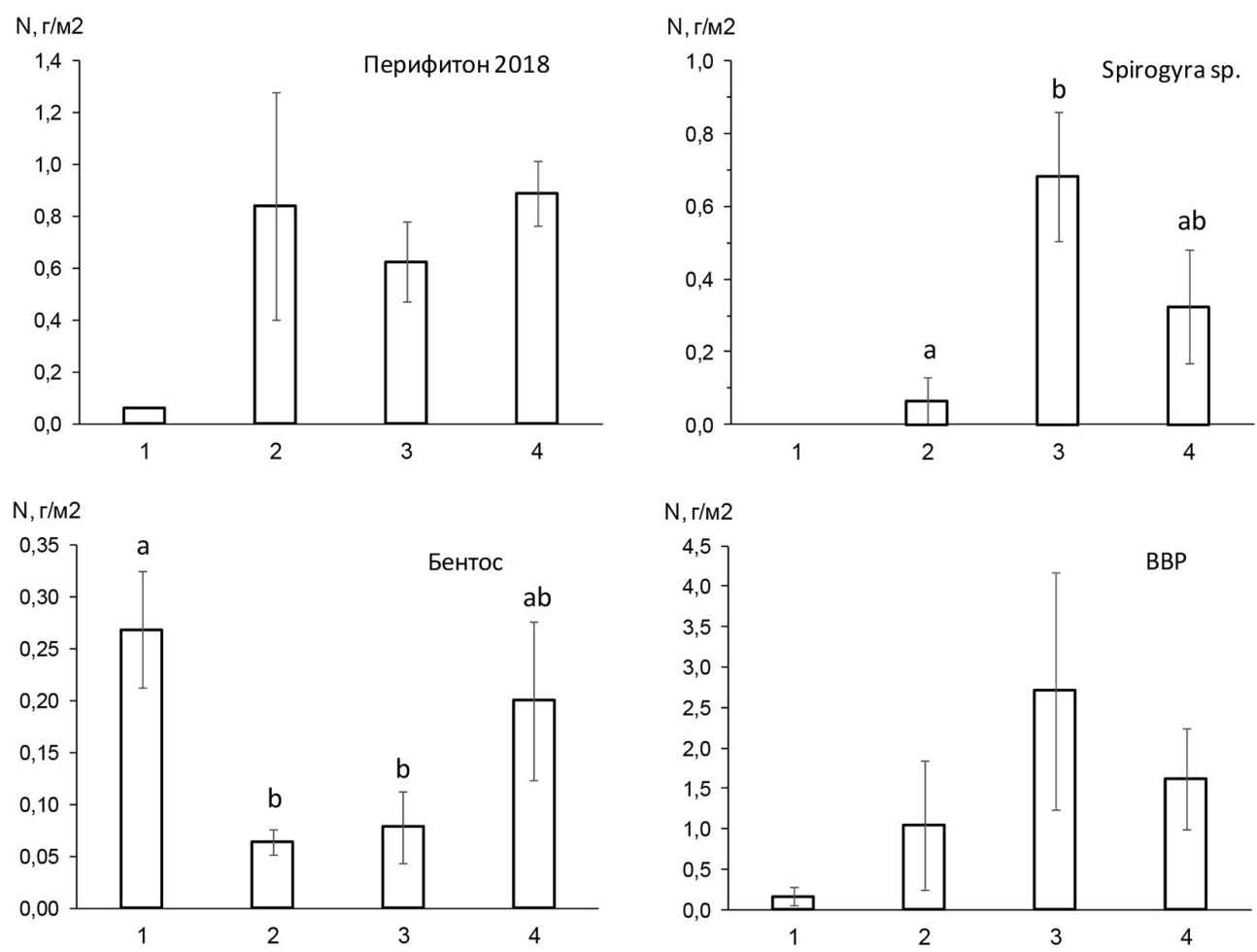

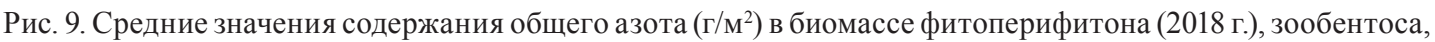
Spirogyra sp. (метафитон) и высших водных растений (BВР) (2018-2019 гг.) и их стандартные ошибки (SE) в Абаканской протоке р. Енисей. Средние, отмеченные одинаковыми буквами, достоверно не отличаются по критерию Краскела-Уоллиса. При недостоверном критерии буквенные обозначения отсутствуют

Fig. 9. Mean values of total nitrogen content $\left(\mathrm{g} / \mathrm{m}^{2}\right)$ in biomasses of phytoperiphyton (2018), zoobenthos, Spirogyra sp. (metaphyton), and higher water plants (2018-2019) ( \pm standard error) in the 'Abakanskaya' anabranch of the Yenisei River. The same letters denote means that are not significantly different based on Kruskal-Wallis test. No letters means that test is not significant

ней части (ст. 3-4) обследованного участка протоки в летние месяцы почти полностью покрыта биомассой макрофитов.

\section{Азот в биомассе фитоперифитона,}

\section{бентоса и макрофитов}

Содержание общего азота в биомассе перифитона на ст. 1 было измерено только в одну дату (31.05.2018), поэтому оценить статистическую значимость различий по данному показателю между рекой и протокой невозможно (рис. 9). Достоверных отличий по величине общего азота, содержащегося в биомассе перифитона, в 2018 г. на ст. 2 - 4 не обнаружено. Среднее значение величи- ны общего азота в биомассе зообентоса на ст. 1 было достоверно выше, чем на ст. 2 и ст. 3 в протоке, тогда как между остальными станциями достоверных различий не было (рис. 9). Величина общего азота, содержащегося в биомассе Spirogyra sp., на ст. 3 была достоверно выше, чем на ст. 2. Достоверных отличий между средними значениями величины общего азота, содержащегося в биомассе высших растений, на разных станциях не обнаружено (рис. 9).

\section{Обсуждение}

Отсутствие достоверных различий между трансектами по скорости течений в толще 
воды (независимо от направлений) и величине потока воды через трансекту (табл. 1) свидетельствует о том, что в Абаканской протоке нет закономерного движения воды сверху вниз по направлению основного потока реки, т.е. стокового течения. Потоки воды, проходящие через трансекты в прямом и обратном направлениях, компенсируют друг друга. Вероятно, течения определяются сложной картиной циркуляций, связанной с ветровыми сгонными и нагонными явлениями и повышением/понижением уровня воды в основном русле.

На станции 1 Абаканской протоки большинство физических и химических показателей воды (температура, $\mathrm{pH}$, содержание $\left.\mathrm{O}_{2}, \mathrm{P}_{\text {обш }}, \mathrm{PO}_{4}-\mathrm{P}, \mathrm{NH}_{4}-\mathrm{N}, \mathrm{NO}_{3}-\mathrm{N}\right)$ находились в пределах, характерных для данного участка p. Енисей (Анищенко и др., 2010; Ponomareva, Ivanova, 2016). Только содержание нитритов в воде на порядок превышало отмеченные нами ранее концентрации на участках, расположенных выше г. Красноярска (Анищенко и др., 2010; Ponomareva, Ivanova, 2016). Вероятно, на ст. 1 Абаканской протоки происходит постоянный водообмен с основным руслом реки.

В фитопланктоне и зоопланктоне ст. 1 в основном доминировали бентосные и планктобентосные виды (табл. 2, 4), доля истинного зоопланктона в общей биомассе была очень низкой (рис. 5). В целом, это согласуется с общими представлениями о том, что в Верхнем Енисее планктон как биоценотически связанное целое отсутствует и представлен небольшим количеством взмученных со дна и вынесенных из затишных участков организмов (Грезе, 1964; Дубовская и др., 2004; Дубовская, 2009). Доминирование в фитоперифитоне диатомовых и зеленых водорослей, а в составе бентофауны амфипод и олигохет характерно для бентосного сообщества Верхнего Енисея в летние месяцы (Sushchik et al., 2007; Anishchenko et al., 2010; Андрианова, 2013). Величина ВПП фитоперифитона также находится в пределах значений, полученных в летние месяцы 2003 - 2006 гг. на участке р. Енисей, расположенном выше г. Красноярска (Kolmakov et al., 2008). Единственным отличием от полученных ранее данных было появление в перифитоне в августе сентябре относительно высокой биомассы (до 15 г/м²) Spirogyra sp. (рис. 8). В предыдущие годы основу биомассы зеленых водорослей составляли виды родов Ulothrix, Palmella, и Stigeoclonium (Sushchik et al., 2007; Anishchenko et al., 2010), a Spirogyra sp. за весь период трехлетних круглогодичных исследований в прибрежном перифитоне встречалась только один раз, причем ее биомасса и численность составляли менее одного процента от общей биомассы фитоперифитона. Считается, что для роста спирогиры оптимальны условия низкой турбулентности, в то время как в прибрежных зонах с существенной волновой активностью она проигрывает конкуренцию диатомовым и другим видам зеленых водорослей (Gladyshev, Gubelit, 2019). Мы предполагаем, что в Абаканской протоке рост спирогиры начинается в глубоководной части и только в период ее массового роста и летнего падения уровня воды она появляется в прибрежном перифитоне на глубинах менее $0,5 \mathrm{м}$.

Ниже дамбы (ст. 2, трансекты III, IV, V) статистически достоверно повышалась минерализация воды (по удельной электропроводности, УЭП) (табл. 1, рис. 3) с максимальным значением 280,1 $\pm 16,7$ мкСм/см (V трансекта). Очевидно, что дорожная дамба, с внешней стороны которой УЭП воды составляла около 160-170 мкСм/см, является существенным 
препятствием к обновлению воды во внутренней части Абаканской протоки, и пропускная способность дренажных труб дамбы в настоящее время очень ограничена. В ином случае значения электропроводности с внешней и внутренней сторон дамбы должны выравниваться. Температура воды возле берега на ст. 2 достоверно не отличалась от речной ст. 1 (рис. 2), однако в глубокой части наблюдалась температурная стратификация столба воды. Низкая температура $\left(8,1-13,4{ }^{\circ} \mathrm{C}\right)$ и повышенная электропроводность придонного слоя воды на данном участке позволяют предположить, что возрастание минерализации связано с поступлением холодных грунтовых вод. Кроме того, нельзя исключать влияния на уровень минерализации поступления ливневых сточных вод, которые сбрасываются в Абаканскую протоку в районе ст. 2. Однократный анализ пробы сливаемой воды летом 2019 г. показал, что ее УЭП составляет 300 мкСм/см.

Несмотря на отсутствие достоверных различий в скоростях течений между ст. 1 и ст. 2 (табл. 1), появление дамбы, очевидно, оказывает существенное влияние на видовой состав и количественные показатели биоты. В планктонном сообществе на ст. 2 появляются признаки, характерные для зарегулированных участков рек и перехода лотической экосистемы в лентическую (Bunn, Arthington, 2002; Poff, Zimmerman, 2010; Wang et al., 2018). То есть в фитопланктоне значительно возрастает доля подвижных жгутиковых форм (рис. 4), причем два вида (Dinobryon sociale var. stipitatum, Cryptomonas erosa) на этой станции выходят на доминирующее положение (табл. 2). Кроме того, увеличивается биомасса зоопланктона и значительно возрастает доля представителей истинного планктона, в числе доминантов появляются планктонные виды, а число обнаруженных таксонов по сравнению с рекой возрастает в два раза (рис. 5, табл. 4). Тем не менее биомасса фито- и зоопланктона остается относительно низкой. Несмотря на низкие скорости течения (движения водных масс) (0,36-0,55 м/с, табл. 1), в период измерений они были выше критической для развития лимнического зоопланктона 0,25 м/с (Дубовская, 2009), т.е. высокая подвижность водных масс и их турбулентность препятствуют его развитию в толще воды. Основным продуцентом в прибрежье на ст. 2 продолжает оставаться фитоперифитон, ВПП которого на порядок возрастает по сравнению с рекой (рис. 4) за счет интенсивного роста Spirogyra sp. (рис. 8). Следует отметить, что Spirogyra sp. появляется в прибрежной зоне ст. 2 уже в июне, на два месяца раньше, чем на речной ст. 1. Кроме того, на этой станции появляются заросли макрофитов (рис. 8). 3ообентос ниже дамбы не отличается от речного по биомассе и соотношению групп, однако общее число таксонов существенно возрастает (рис. 6, табл. 5).

В районе ст. 3 и 3 а минерализация по сравнению со ст. 2 снижается и возвращается к значениям, характерным для реки (рис. 3), а температура воды в результате поступления подогретых вод ТЭЦ достоверно повышается (рис. 2). Литературные данные о влиянии теплового загрязнения на водные экосистемы противоречивы - описаны случаи как увеличения, так и снижения таксономического разнообразия и количественных показателей бентосных и планктонных сообществ под влиянием повышения температуры среды в результате сброса подогретых вод (например, Zargar, Ghosh, 2006; Czerniawski et al., 2013; Ruzickova et al., 2017; Nashaat et al., 2019). B Абаканской протоке на ст. 3 не обнаружено достоверных отличий биомассы планктона и бентоса, а также первичной продукции от ст. 2 (рис. 4-6). Однако следует отметить тенден- 
цию к снижению на этой станции биомассы зоопланктона, перифитона и ВПП. Вероятно, планктонные и бентосные организмы на этом участке угнетены какими-либо физическими (например, высокой температурой из-за сброса теплых вод) или химическими (сброс загрязненных вод) факторами. Действительно, на ст. 3 наблюдается достоверное возрастание индексов сапробности, рассчитанных по численности перифитона, зоопланктона и зообентоса, что свидетельствует об увеличении органической нагрузки (рис. 7). На рост макрофитов данный фактор существенного воздействия, судя по всему, не оказывал (рис. 8). Хотя в обрастаниях камней прибрежной зоны на этом участке Spirogyra sp. была встречена только в июне и июле 2018 г., и ее биомасса была гораздо ниже, чем на ст. 2, однако на поверхности воды скопления этих зеленых водорослей присутствовали постоянно (рис. 8).

Видовой состав фито- и зоопланктона на ст. 3 существенно не изменился. Характерной особенностью перифитона ст. 3 было увеличение доли цианопрокариот и появление среди доминирующих видов O. limosa - обитателя стоячих или медленно текущих вод, богатых биогенами. В то же время видовая структура зообентоса значительно изменяется: в биомассу основной вклад начинают вносить пиявки и моллюски, а в доминирующем комплексе встречаются личинки хирономид (рис. 6, табл. 5). Эти изменения, вероятно, вызваны, с одной стороны, повышением температуры воды, а с другой - появлением плотных зарослей макрофитов.

На станции 4, расположенной ниже рыбоводных садков, количественные показатели рассматриваемых звеньев экосистемы достоверно не изменяются (рис. 4-6). В то же время возрастает видовое богатство (число таксонов) зоопланктона, а также таксономическое разнообразие (индекс Шеннона) зоопланктона и зообентоса (рис. 7, табл. 4). Очевидно, что, как и на ст. 3, повышение температуры воды на этом участке приводит к удлинению вегетационного сезона по сравнению с рекой и ст. 2, а относительно небольшая глубина и высокая подводная освещенность способствуют интенсивному росту спирогиры и высшей водной растительности. Именно активный фотосинтез макрофитов и спирогиры в нижней части протоки, вероятно, является причиной возрастания концентрации кислорода в воде ст. 4 (рис. 2). Достоверное повышение величины $\mathrm{pH}$ воды на ст. 4 также косвенно подтверждает высокую интенсивность фотосинтеза. Известно, что в результате интенсивного фотосинтеза в донных матах спирогиры образуются пузырьки кислорода, на которых они всплывают в толщу воды (Berry, Lembi, 2000). Таким образом, небольшая глубина протоки и высокая придонная освещенность способствуют не только росту донных макроводорослей, но и их переходу к метафитонной стадии вегетации. Плотные заросли макрофитов, вероятно, способствуют изменению типа грунта - ранее было показано, что растения задерживают взвешенные частицы, что приводит к заиливанию донных отложений (French, Chambers, 1996). Мaccoвое развитие высшей растительности и увеличение разнообразия типов грунта в свою очередь увеличивает разнообразие экологических ниш для бентосных и фитофильных животных, что приводит к максимальному видовому разнообразию на этом участке зоопланктона и зообентоса. Величины индексов сапробности, рассчитанных по численности перифитона и зоопланктона, на этой станции достоверно уменьшались, а индекс сапробности по зообентосу не отличался от ст. 3, но тоже имел тенденцию к уменьшению. Это свидетельствует о снижении органического загрязнения на ст. 4, что также может благо- 
приятно повлиять на видовое разнообразие беспозвоночных.

Известно, что эксплуатация аквакультурного хозяйства приводит к увеличению биогенной нагрузки на водоем в результате разложения не съеденных кормов и физиологических выделений рыб: в воде возрастает содержание растворенного углерода, азота и фосфора, однако основными компонентами обычно являются аммоний и мочевина (Podemski, Blanchfield, 2006; Ruiz-Zarzuela et al., 2009; Mavraganis et al., 2017). В Абаканской протоке на ст. 4, расположенной ниже по течению от рыборазводного хозяйства, не было достоверных отличий по содержанию в воде форм азота по сравнению со ст. 3 (рис. 2). Хотя, в отсутствие стокового течения, само понятие «ниже по течению» в данном случае утрачивает свой истинный гидродинамический смысл. Отсутствие различий может объясняться также высокой скоростью потребления азота первичными продуцентами. Известно, что фоновая концентрация лимитирующего рост фактора всегда находится на одном и том же уровне и не зависит от его концентрации во входном потоке (принцип аутостабилизации) (Дегерменджи и др., 1979). В то же время очевидна тенденция к увеличению в протоке (ст. 2-4) по сравнению с рекой (ст. 1) количества азота, связанного в биомассе перифитона, метафитонных матов и высшей водной растительности (рис. 9), что предполагает увеличение азотной нагрузки на участке протоки, расположенном ниже дамбы, на котором нет стокового течения, и, вероятно, происходит лишь ветровое перемешивание (ст. 2-4).

\section{Заключение}

Таким образом, основным фактором, вызывающим перестройку сообщества Абаканской протоки, является уменьшение ее проточности вследствие малой пропускной способности дренажных труб, расположенных в дамбе. Именно на ст. 2 происходят основные изменения структурных и количественных показателей всех компонентов экосистемы. На нижележащих станциях повышение температуры и биогенной нагрузки только способствует более интенсивному развитию высшей растительности и макроводорослей, что, в свою очередь, приводит к постепенному изменению видового состава и увеличению таксономического разнообразия беспозвоночных животных. За исключением проточности, другие исследованные факторы - тепловое, биогенное и органическое загрязнение - в связи с гидрологическими особенностями изученного участка, а именно отсутствием на нем стокового течения, очевидно, действовали на экосистему в комплекce, и их специфические эффекты в явном виде не проявлялись.

Однако увеличение проточности как наиболее очевидная мера борьбы с массовым ростом Spirogyra sp. неизбежно приведет к снижению температуры воды и потере протокой ее рекреационных свойств. Поэтому дальнейшим направлением данных исследований должно стать создание математической модели экосистемы Абаканской протоки для поиска оптимального баланса между проточностью и качеством воды, с одной стороны, и сохранением рекреационных качеств протоки - с другой.

\section{Список литературы / References}

Алимов А. Ф., Богатов В. В., Голубков С. М. (2013) Продукиионная гидробиология. СПб., Наука, 343 с. [Alimov A. F., Bogatov V. V., Golubkov S. M. (2013) Production hydrobiology. Saint Petersburg, Nauka, 343 p. (in Russian)] 
Андрианова А.В. (2013) Динамика развития енисейского зообентоса в нижнем бьефе Красноярской ГЭС. Вестник Томского государственного университета. Биология, 1: 74-88 [Andrianova A.V. (2013) Dynamics of Yenisei zoobenthos evolution in the downstream of Krasnoyarsk hydroelectric power station. Tomsk State University Journal of Biology [Vestnik Tomskogo Gosudarstvennogo Universiteta. Biologiya], 1: 74-88 (in Russian)]

Анищенко О. В. (2008) Влияние гидрофизических факторов на флуоресцентные характеристики фитопланктона в поверхностном слое малого эвтрофного водохранилища Бугач. Сибирский экологический журнал, 2: 303-313 [Anishchenko O. V. (2008) Effect of hydrophysical factors on the fluorescence characteristics of phytoplankton in the surface layer of a small eutrophic water reservoir Bugach. Contemporary Problems of Ecology [Sibirskii ekologicheskii zhurnal], 2: 303-313 (in Russian)]

Анищенко О. В., Гладышев М.И., Кравчук Е.С., Калачева Г.С., Грибовская И. В. (2010) Оценка антропогенного загрязнения р. Енисей по содержанию металлов в основных компонентах экосистемы на участках, расположенных выше и ниже г. Красноярска. Журнал Сибирского федерального университета. Биология, 3(1): 82-98 [Anishchenko O. V., Gladyshev M.I., Kravchuk E. S., Kalacheva G. S., Gribovskaya I. V. (2010) Assessment of the Yenisei river anthropogenic pollution by metals concentrations in the main ecosystem compartments upstream and downstream Krasnoyarsk city (Russia). Journal of Siberian Federal University. Biology [Zhurnal Sibirskogo federal'nogo universiteta. Biologiya], 3(1): 82-98 (in Russian)]

Баринова С. С., Медведева Л. А., Анисимова О. В. (2000) Водоросли-индикаторы в оценке качества окружающей среды. Москва, ВНИИприроды, 150 с. [Barinova S. S., Medvedeva L.A., Anisimova O. V. (2000) Algae as indicators of environmental quality. Moscow, All-Russian Scientific Research Institute for Environmental Protection, 150 p. (in Russian)]

Водоросли. Справочник (1989) Вассер С.П. (ред.) Киев, Наукова думка, 608 с. [Algae. Reference book. (1989) Vasser S.P. (Ed.) Kiev, Naukova dumka, 608 p. (in Russian)]

ГОСТ 33045-2014. Межгосударственный стандарт. Вода. Методы определения азотсодержащих веществ. (2015) Москва, Стандартинформ, 20 с. [GOST 33045-2014. Interstate standard. Water. Nitrogen-containing substances measurement methods. (2015) Moscow, Standartinform, 20 p. (in Russian)]

Грезе В.Н. (1964) Биологический сток реки Енисея в районе Красноярска. Рыбное хозяйство Восточной Сибири. Труды Сибирского отделения ГосНИОРХ. Т. VIII. Красноярск, с. 67-109 [Greze V.N. (1964) Biological sink of the Yenisei River near the city of Krasnoyarsk. Fishery of the Eastern Siberia. Proceedings of Siberian Branch of the State Research Institute of Lake and River Fisheries. Vol. 8. Krasnoyarsk, p. 67-109 (in Russian)]

Дегерменджи А.Г., Печуркин Н.С., Шкидченко А.Н. (1979) Аутостабилизация контролирующих рост факторов в биологических системах. Новосибирск, Наука [Degermendzhy A. G., Pechurkin N. S., Shkidchenko A. N. (1979) Autostabilization of growth-controlling factors in biological systems. Novosibirsk, Nauka (in Russian)]

Дубовская О. П., Гладышев М. И., Махутова О.Н. (2004) Сток лимнического зоопланктона через высоконапорную плотину и его судьба в реке с быстрым течением (на примере плотины Красноярской ГЭС на р. Енисей). Журнал общей биологии, 65(1): 81-93 [Dubovskaya O.P., Gladyshev M. I., Makhutova O. N. (2004) Limnetic zooplankton passing through a high-head dam 
and their fate in a river with high current velocity (case of the Krasnoyarsk hydroelectric power station on the Yenisey river). Journal of General Biology [Zhurnal obshchei biologii], 65(1): 81-93 (in Russian)]

Дубовская О.П. (2009) Не связанная с хищниками смертность планктонных ракообразных, ее возможные причины (обзор литературы). Журнал общей биологии, 70(2): 168-192 [Dubovskaya O.P. (2009) Non-predatory mortality of the crustacean zooplankton, and its possible causes (a review). Journal of General Biology [Zhurnal obshchei biologii], 70(2): 168-192 (in Russian)]

Катанская В. М. (1981) Высшая водная растительность континентальных водоемов СССР. Методы изучения. Л., Наука, 187 с. [Katanskaya V.M. (1981) Higher aquatic vegetation of continental water bodies of USSR. Research methods. Leningrad, Nauka, 187 p. (in Russian)]

Макрушин А. В. (1974) Биологический анализ качества вод. Винберг Г. Г. (ред.) Л., Наука, 60 c. [Makrushin A. V. (1974) Biological analysis of water quality. Vinberg G. G. (ed.) Leningrad, Nauka, 60 p. (in Russian)]

Методика изучения биогеоценозов внутренних водоемов (1975) М., Наука, 242 с. [Methods of studying biogeocenoses of inland water bodies (1975) Moscow, Nauka, 242 p. (in Russian)]

РД 52.24.382-2006. Массовая концентрация фосфатов и полифосфатов в водах. Методика выполнения измерений фотометрическим методом (2006) Ростов-на-Дону, ГУ «Гидрохимический институт», 27 с. [RD52.24.382-2006. Mass concentration of phosphates and polyphosphates in water. Procedure of measurement by photometric method (2006) Rostov-on-Don, Institute of Hydrochemistry, 27 p. (in Russian)]

РД 52.24.387-2006. Массовая кониентрация фосфора общего в водах. Методика выполнения измерений фотометрическим методом после окисления персульфатом калия (2006) Ростовна-Дону, ГУ «Гидрохимический институт», 26 с. [RD52.24.387-2006. Mass concentration of total phosphorus in water. Procedure for measurement by photometric method after oxidation by potassium persulfate (2006) Rostov-on-Don, Institute of Hydrochemistry, 26 p. (in Russian)]

РД 52.24.309-2011. Организаџия и проведение режимных наблюдений за состоянием и загрязнением поверхностных вод суши (утв. Росгидрометом 25.10.2011). Электронный ресурс: www. consultant.ru [RD52.24.309-2011. Organization and conduct of monitoring of surface waters condition and pollution (Approved by Federal Service for Hydrometeorology and Environmental Monitoring 25.10.2011). Online resource: www.consultant.ru (in Russian)]

РД 52.24.380-2017. Массовая кониентрация нитратного азота в водах. Методика измерений фотометрическим методом с реактивом Грисса после восстановления в кадмиевом редукторе (2017) Ростов-на-Дону, 30 с. [RD52.24.380-2017. Mass concentration of nitrate nitrogen in water. Measurement technique by photometric method with Griess reagent after reduction in cadmium reducer (2017) Rostov-on-Don, 30 p.]

Руководство по гидробиологическому мониторингу пресноводных экосистем (1992) СПб., Гидрометеоиздат, 318 c. [Guidelines for hydrobiological monitoring of freshwater ecosystems (1992) Saint Petersburg, Gidrometeoizdat, 318 p. (in Russian)]

Унифицированные методы исследования качества вод. Часть ІІІ. Методы биологического анализа вод. Приложение 2. Атлас сапробных организмов. (1977) М., СЭВ, 227 с. [Unified methods of water quality assessment. Part III. Methods of biological water analysis. Supplement 2. Atlas of saprobic organisms. (1977) Moscow, SEV, 227 p. (in Russian)] 
Alberty M.S, Germineaud C., Sprintall J., Ganachaud A., Cravatte S. (2017) SPICE mooring data report: description and quality control. UC San Diego, Scripps Institution of Oceanography. Retrieved from https://escholarship.org/uc/item/6xd149s8

Anishchenko O. V., Gladyshev M. I., Kravchuk E. S., Ivanova E. A., Gribovskaya I. V., Sushchik N. N. (2010) Seasonal variations of metal concentrations in periphyton and taxonomic composition of the algal community at a Yenisei River littoral site. Central European Journal of Biology, 5(1): 125-134

Berry H.A., Lembi C. A. (2000) Effects of temperature and irradiance on the seasonal variation of a Spirogyra (Chlorophyta) population in a midwestern lake (U.S.A.). Journal of Phycology, 36: 841-851

Bunn S. E., Arthington A.H. (2002) Basic principles and ecological consequences of altered flow regimes for aquatic biodiversity. Environmental Management, 30(4): 492-507

Burford M. A., Carey C. C., Hamilton D. P., Huisman J., Paerl H. W., Wood S. A., Wulff A. (2020) Perspective: Advancing the research agenda for improving understanding of cyanobacteria in a future of global change. Harmful Algae, 91: 101601

Czerniawski R., Pilecka-Rapacz M., Domagała J. (2013) Zooplankton communities of inter-connected sections of lower River Oder (NW Poland). Central European Journal of Biology, 8(1): 18-29

French T. D., Chambers P. A. (1996) Habitat partitioning in riverine macrophyte communities. Freshwater Biology, 36(3): 509-520

Gaevsky N. A., Kolmakov V.I., Popelnitsky V. A., Gold V. M., Dubovskaya O.P. (2000) Evaluation of the effect of light intensity on the measurement of the photosynthetic rate in plankton microalgae by the chlorophyll fluorescence method. Russian Journal of Plant Physiology, 47(6): 820-825

Gladyshev M. I., Gubelit Y.I. (2019) Green tides: new consequences of the eutrophication of natural waters (invited review). Contemporary Problems of Ecology, 12(2): 109-125

Gladyshev M. I., Sushchik N. N., Kolmakova A. A., Kalachova G. S., Kravchuk E. S., Ivanova E. A., Makhutova O. N. (2007) Seasonal correlations of elemental and $\omega-3$ PUFA composition of seston and dominant phytoplankton species in a eutrophic Siberian Reservoir. Aquatic Ecology, 41: 9-23

Kelley D. E. (2018) Oceanographic analysis with R. New York, Springer-Verlag

Kirk J. T.O. (2010) Light and photosynthesis in aquatic ecosystems. UK, Cambridge University Press, $649 \mathrm{p}$.

Kolmakov V.I., Anishchenko O. V., Ivanova E. A., Gladyshev M. I., Sushchik N. N. (2008) Estimation of periphytic microalgae gross primary production with DCMU-fluorescence method in Yenisei River (Siberia, Russia). Journal of Applied Phycology, 20: 289-297

Mavraganis T., Thorarensen H., Tsoumani M., Nathanailides C. (2017) On the environmental impact of freshwater fish farms in Greece and in Iceland. Annual Research \& Review in Biology, 13(1): 1-7

Nashaat M.R., Merhoon K. A., Salman S. K., Abbas E.K., Ali E. H. (2019) Impact of Al-Rasheed Power Plant effluents on phytoplankton biodiversity in Tigris River, Southern Baghdad. Journal of Physics: Conference Series, 1234(1): 012064

Nusch E. A. (1980) Comparison of different methods for chlorophyll and phaeopigment determination. Archiv für Hydrobiologie, 14: 14-36

Podemski C.L., Blanchfield P. J. (2006) Overview of the environmental impacts of Canadian freshwater aquaculture. A scientific review of the potential environmental effects of aquaculture in aquatic ecosystems. Canadian Technical Report of Fisheries and Aquatic Sciences, 2450: 30-79 
Poff N. L., Zimmerman J.K.H. (2010) Ecological responses to altered flow regimes: a literature review to inform the science and management of environmental flows. Freshwater Biology, 55: 194-205

Ponomareva Yu.A., Ivanova E. A. (2016) Ratio between living and dead cells and the size structure of the Yenisei River phytoplankton downstream of the Krasnoyarsk Hydroelectric Power Station. Contemporary Problems of Ecology, 9(5): 582-589

Ruiz-Zarzuela I., Halaihel N., Balcazar J.L., Ortega C., Vendrell D., Perez T., Alonso J. L., de Blas I. (2009) Effect of fish farming on the water quality of rivers in northeast Spain. Water Science and Technology, 60(3): 663-671

Ruzickova S., Weissova V., Uher B., Helesic J. (2017) Macroinvertebrate herbivores and epilithon algae community of a stream affected by mineralized heated mining water inflow. Annales de LimnologieInternational Journal of Limnology, 53: 189-201

Schultz J. G.E., Kovatch J. J., Anneken E. M. (2013) Bacterial diversity in a large, temperate, heavily modified river, as determined by pyrosequencing. Aquatic Microbial Ecology, 70: 169-179

Sladecek V. (1973) System of water quality from biological point of view. Archiv für Hydrobiologie, 7: $1-218$

Søndergaard M., Jeppesen E. (2007) Anthropogenic impacts on lake and stream ecosystems, and approaches to restoration. Journal of Applied Ecology, 44: 1089-1094

Sushchik N. N., Gladyshev M. I., Kravchuk E. S., Ivanova E. A., Ageev A. V., Kalachova G. S. (2007) Seasonal dynamics of long-chain polyunsaturated fatty acids in littoral benthos in the upper Yenisei river. Aquatic Ecology, 41: 349-365

Tolomeev A. P., Anishchenko O. V., Kravchuk E. S., Kolmakova O. V., Glushchenko L. A., Makhutova O.N., Kolmakova A. A., Kolmakov V. I., Trusova M. Yu., Sushchik N. N., Gladyshev M.I. (2014) Component elements of the carbon cycle in the middle and lower Yenisei River. Contemporary Problems of Ecology, 7(4): 489-500

Walseng B., Hessen D. O., Halvorsen G., Schartau A. K. (2006) Major contribution from littoral crustaceans to zooplankton species richness in lakes. Limnology Oceanography, 51(6): 2600-2606

Wang F., Maberly S. C., Wang B., Liang X. (2018) Effects of dams on riverine biogeochemical cycling and ecology. Inland Waters, 8(2): 130-140

Wegl R. (1983) Index für die Limnosaprobitat. Wasser und Abwasser. B. 26. 175 p.

Zargar S., Ghosh T. K. (2006) Influence of cooling water discharges from Kaiga nuclear power plant on selected indices applied to plankton population of Kadra reservoir. Journal of Environmental Biology, 27(2): 191-198 